\title{
Coal Resources of
}

Butler County,

\section{Pennsylvania}

By ELMER D. PATTERSON and J. A. VAN LIEU

COAL RESOURCES OF WESTERN PENNSYLVANIA

G E O L O G I C A L S U R V E Y B U L L E T I N 1143-C

Prepared in cooperation with the

Pennsylvania Geological Survey

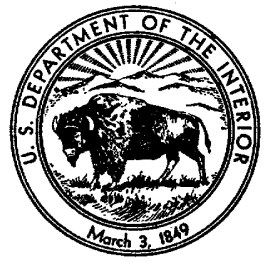




\section{UNITED STATES DEPARTMENT OF THE INTERIOR}

ROGERS G. B. MOR'TON, Secretary

\section{GEOLOGIGAL SURVEY}

W. A. Radlinski, Acting Director

Library of Congress catalog-card No. 76-172971 


\section{CONTENTS}

Page

Abstract

Introduction ........ 2

Previous work

Acknowledgments.

Stratigraphy as related to coal beds

Mississippian rocks _... 4

Pennsylvanian rocks.

Pottsville Group ......... 6

Quakertown coal. 7

Mercer coals

Homewood coal .

Allegheny Group

Brookville(?) coal-... 9

Clarion coal__._. 10

Scrubgrass coal

Kittanning coals.-.-.

Freeport coals....

Conemaugh Formation. 14

Mahoning coal_._.

Brush Creek coal

Bakerstown coal._.

Harlem coal _.

Duquesne coal _.

Wellersburg coal

Quaternary deposits_._. 16

Structure_._. 17

Coal resources

Methods of preparing estimates 30

Classification according to characteristics of the coal _........ 30

Classification according to relative abundance of information.-- $\quad 30$

Distinction between original, remaining, and recoverable resources_ $\quad 32$

Methods of recording data and making calculations._._._._._. 32

Previous estimates of resources in Butler County

Quality of coal .

Production of coal

Conclusions.-.

Selected references... 41 


\section{ILLUSTRATIONS}

Plate 1. Geologic map of Butler County.

[Plates are in pocket]

2. Stratigraphic sections of rocks of Pennsylvanian age in Butler County.

3. Maps showing coal-resource areas and isopachs for coal beds in Butler County.

Figdre 1. Map of western Pennsylvania and adjoining States showing location of Butler County in the northern Appalachian coal field

2. Map showing townships and major structural axes in Butler County

3. Outline map of Butler County showing $71 / 2-$ minute-quadrangle areas used for breakdown of coal-resource data

4. Graph showing annual production of coal in Butler County, 1881-1965

5. Graph showing production of coal in Butler County, expressed as percentage of total production of bituminous coal in Pennsylvania, 1881-1965 .

\section{TABLES}

TABLE 1. Estimated original coal resources of Butler County under less than 60 feet of overburden, by quadrangles and by beds......-

2. Estimated original coal resources of Butler County under 601,000 feet of overburden, by beds and by quadrangles.

3. Estimated original coal resources of Butler County, by thickness of overburden and by beds

4. Estimated remaining and recoverable coal resources of Butler County as of January 1, 1966, according to thickness of overburden.

5. Classification of coals by rank

6. Analyses of coal in Butler County 


\title{
COAL RESOURGES OF WESTERN PENNSYLVANIA
}

\section{COAL RESOURGES OF BUTLER COUNTY, PENNSYLVANIA}

\author{
By E. D. Patterson and J. A. Van Lieu
}

\begin{abstract}
Butler County is in west-central Pennsylvania in the northern part of the Appalachian coal field. The county is underlain by coal-bearing rocks of Pennsylvanian age, which are about 830 feet thick. These rocks are divided, in ascending order, into the Pottsville and Allegheny Groups and the Conemaugh Formation. The beds dip gently southward, so that the oldest rocks crop out in valleys in the northern part of the county and the youngest rocks crop out on hills in the southern part. The Pennsylvanian rocks in the northwestern part of the county are partly obscured by unconsolidated glacial deposits.

The sequence of coal-bearing Pennsylvanian rocks includes 11 coal beds, which range in thickness from less than 14 to more than 42 inches. The coal is of highvolatile $A$ bituminous rank. It is high in heat value and is generally ideal for industrial use.

The estimated original resources in the 11 coal beds before mining began totaled 3,678 million tons, of which 647 million tons is classed as measured, 1,467 million tons as indicated, and 1,564 million tons as inferred. The resources are concentrated largely in the Upper and Lower Freeport, Middle and Lower Kittanning, and Clarion coal beds. Of the estimated original resources of 3,678 million tons, about 222 million tons had been mined or lost in mining as of January 1, 1966. As of that date, the remaining resources in the ground totaled 3,456 million tons, and the estimated recoverable resources totaled 1,883 million tons.

Of the remaining resources of 3,456 million tons, 518 million tons, or 15 percent, is 60 feet or less below the surface and is readily accessible by strip-mining methods. By a process of extrapolation, about 25 percent of the remaining resources, or 864 million tons, is estimated to be generally less than 100 feet below the surface. Because of the large amount of strippable coal in the county, most of the coal produced since 1945 has been recovered by strip-mining methods. Before 1945, most of the coal was mined by underground methods.

Because of the rapid increase in strip mining, accompanied by a trend toward use of larger machinery, deeper mining, and multiple-bed stripping, the percentage of Butler County coal within reach by future strip-mining techniques could be larger than the figures mentioned.
\end{abstract}




\section{INTRODUCTION}

Butler County covers an area of 794 square miles in west-central Pennsylvania in the northern part of the Appalachian coal field (fig. 1). The city of Butler, the county seat, is about 34 miles north of Pittsburgh.

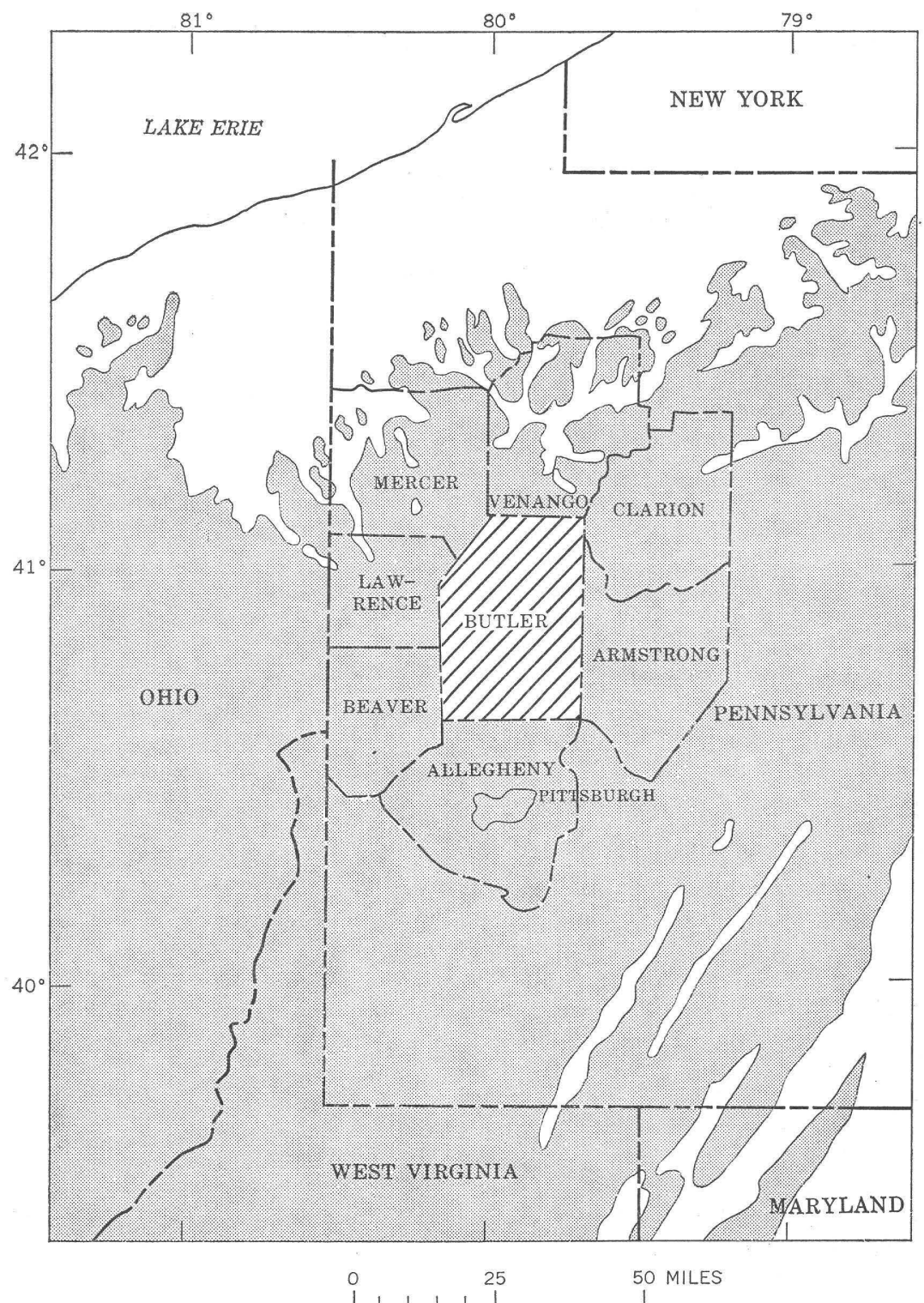

Figure 1.-Map of western Pennsylvania and adjoining States showing location of Butler County in the northern Appalachian coal field (shaded). 
Most of the county is underlain by coal, which constitutes an important natural resource. This report, prepared in cooperation with the Pennsylvania Geological Survey, is intended to show the distribution, thickness, and resources of this coal as an aid in planning for the future development of western Pennsylvania.

Much of Butler County is a broad, moderately dissected upland about 1,000 feet above sea level. This upland is incised by deep valleys of Connoquenessing Creek and its many tributaries. The highest point in the county (about 1,580 feet) is near Annisville in the northeastern part of the county, and the lowest point ( 860 feet) is in the Allegheny River valley in the extreme northeast corner. Local relief of $200-400$ feet is common near the major streams. All parts of the county are accessible by primary and secondary roads and by railroads.

\section{PREVIOUS WORK}

The stratigraphy and structure of Butler County were first described by White (1879) and by Chance (1879). These older studies were based on reconnaissance techniques appropriate to the needs of the time. Reports by Munn (1911) and by Hughes (1933) were of considerable value in the present study in that they contain data on abandoned mines and prospects. Reese and Sisler (1928, p. 39-51) and Sisler (1932, p. 78-94) provided excellent summaries of the geology and coal resources from information accumulated to the late 1920's. Poth (1963) described the geology and hydrology of northwesternmost Butler County.

As part of the reevaluation of the coal resources of the county, the accompanying geologic map (pl. 1) was prepared to show the distribution of coal-bearing rocks and major coal beds. This map incorporates data assembled by the authors, through tracing of outcrops, and information obtained from mine maps and records, aerial photographs, and logs of drill holes. Stratigraphic relations and nomenclature of members and beds in the sequence of bedded rocks are shown on the diagrammatic sections (pl.2).

\section{ACKNOWLEDGMENTS}

The authors are indebted to many individuals and organizations associated with the coal-mining industry in Butler County who were most helpful in loaning maps and in showing mining properties. The Michigan Limestone Division of the U.S. Steel Corp., the Pennsylvania Geological Survey, the Pennsylvania Department of Mines, and the Pennsylvania Department of Health at Greensburg were particularly helpful. Helen Nace calculated the coal tonnages 
and prepared the accompanying tables of coal resources. Flora $\mathrm{K}$. Walker prepared other tables, figures, and graphs. David A. Strate assisted in the compilation of the geologic map (pl. 1).

\section{STRATIGRAPHY AS RELATED TO COAL BEDS}

The consolidated rocks exposed in Butler County are of Mississippian and Pennsylvanian ages. Rocks of late Mississippian age, 150-200 feet thick, crop out only in the northeastern corner of the county in deep ravines of streams tributary to the Allegheny River.

The rocks of Late Mississippian age are overlain disconformably by a sequence of rocks of Pennsylvanian age about 830 feet thick. This sequence includes, from oldest to youngest, the Pottsville Group, about 170 feet thick; the Allegheny Group, about 280 feet thick; and the lower part of the Conemaugh Formation, about 380 feet thick. The upper part of the Conemaugh has been removed by erosion.

The northwestern corner of the county is covered by thick deposits of glacial drift, and most of the northern part of the county is covered by glacial-lake and outwash deposits, all of Pleistocene age.

The distribution of the rock units in the county is shown on the geologic map (pl. 1), and the stratigraphic relations and nomenclature of members and beds in the sequence of Pennsylvanian and Mississippian ages are shown on the stratigraphic sections (pl. 2). The stratigraphic nomenclature used on plate 2 differs somewhat from that of Carswell and Bennett (1963) but closely follows that of Poth (1963).

\section{MISSISSIPPIAN ROCKS}

Rocks of Mississippian age, termed the Burgoon Sandstone (Butts, 1904, p. 5), are exposed in the valley of the Allegheny River in the northeastern corner of the county and in several deep ravines of streams tributary to the Allegheny River. A sequence of Burgoon sandstone and siltstone beds, 150-200 feet thick, is exposed near the base of a high cliff near Emlenton, Venango County. The upper part of the Burgoon includes shale, siltstone, and several thin coal beds.

The top of the Mississippian sequence is marked by a disconformity representing erosion or nondeposition of several hundred feet of beds. The contact between the two systems has not been accurately located because, where observed, the strata are similar and poorly 
exposed, and diagnostic fossils have not been found. A generalized section of exposed rocks follows.

Generalized section of exposed Mississippian rocks in northeastern Butler County

Pennsylvanian System.

Mississippian System:

Burgoon sandstone:

\begin{tabular}{rrr}
\multicolumn{3}{c}{$\begin{array}{c}\text { Approximate } \\
\text { thickness }\end{array}$} \\
\hline Feet & Inches \\
27 & \\
-30 & \\
- & & 4 \\
- & 4 & \\
- & 4 & \\
- & 4 & \\
- & 3 & \\
- & 4 & \\
- & 3 & 6 \\
$y$ & & \\
- & 1 & 6 \\
- & 6 & 4 \\
- & & 6
\end{tabular}

Shale, partly concealed.....

Sandstone, medium-grained; uneven bedding, forms cliff...-

Coaly zone in sandstone........

Sandstone, very fine grained, micaceous

Coal, shaly

Sandstone, very fine grained, micaceous . . . . . . . . . . .

Siltstone............

Shale

112

Shale, dark-gray; thin coaly zone at top.............

Sandstone, thin-bedded, and interbedded shale

Sandstone, very fine grained, slightly micaceous, evenly bedded. .

Shale, fissile

Siltstone, medium-light gray

Sandstone; massive in overlapping lenses

200

Base concealed.

Total exposed Burgoon sandstone

\section{PENNSYLVANIAN ROCKS}

The rocks of Pennsylvanian age in Butler County consist of interbedded sandstone, siltstone, shale, limestone, coal, and clay, listed in approximate order of decreasing abundance. Sandstone forms weathered brown ledges and cliffs and is commonly thin bedded and micaceous. Siltstone and shale are commonly interbedded, and both are generally gray to dark gray on fresh surfaces and brown on weathered surfaces. Red and green shale are common in the Upper Pennsylvanian sequence. Locally, the shale contains abundant fragments of carbonaceous material and impressions of leaves and plant stems or fragments of fossil shells; nodules or thin beds of ironstone are common in some carbonaceous shale units.

Thin lenticular beds of limestone of both marine and fresh-water origin are conspicuous at several places in the sequence. The marine limestone ranges from thin bedded to massive and is generally coarsely crystalline and fossiliferous. The fresh-water limestone ranges from thin-bedded to nodular and is generally gray, microcrystalline, nonfossiliferous, and in many places, conglomeratic or brecciated.

The coal beds are irregular in thickness and are generally less than 3 feet thick, but they are commonly continuous throughout much of the county. Locally they grade into coaly shale, and at a few places they are cut out by channel-sandstone deposits. Underclay, which 
lies beneath most coal beds, is light to dark gray and commonly contains impressions of roots.

The rocks of Pennsylvanian age were deposited in a near-shore marine or continental environment. Several units are distinctive and continuous and are very useful in determining position in the stratigraphic sequence and thus in locating coal beds. The Pennsylvanian rocks in Butler County have been divided into the Pottsville and Allegheny Groups and the Conemaugh Formation, as described below.

\section{POTTSVILLE GROUP}

The Pottsville Group, of Early and Middle Pennsylvanian age, comprises the oldest rocks of Pennsylvanian age exposed in Butler County. The name was applied by White $(1878$, p. 66$)$ to rocks in western Pennsylvania that are stratigraphically equivalent to the Pottsville of the anthracite region of eastern Pennsylvania (Lesley, 1876, p. 221-227). This usage has been extended to and used in Butler County and vicinity by Richardson (1936), Poth (1963), and the present writers.

The Sharon Formation, which is at the base of the Pottsville Group in Mercer County and eastern Ohio, was not identified in Butler County. The name Sharon Formation was given by White (1880, p. 51-58) to coal, shale, sandstone, and conglomerate exposed near the city of Sharon, Pa. According to Poth (1963, p. 18), the Burgoon Sandstone and the Sharon Formation are not known to occur in the same area.

The Pottsville Group in Butler County is about 170 feet thick. It has been divided for purposes of mapping and discussion into three formations; from oldest to youngest, they are Connoquenessing, Mercer, and Homewood Formations. Most of the discussion that follows is confined to the coal beds and to the associated units that have diagnostic value in locating coal beds or in determining stratigraphic position in the sequence. The lithology and range in thickness of all units are described in the accompanying generalized section.

\section{Generalized section of the exposed Pottsville Group in Butler County}

Range in thickness

Homewood Formation:

Feet Inches

Sandstone, tannish-white to reddish-purple, medium- to coarse-grained, quartzose, iron-stained, crossbedded, lenticular. May consist of two beds.........

Coal, Homewood

Mercer Formation:

Shale, dark-gray; contains lenses of sandstone _._. . . . . . . 40

Coal, Upper(?) Mercer.

Shale or very fine grained sandstone, gray _..............

Coal, Lower(?) Mercer.

Shale _. 
Generalized section of the exposed Pottsville Group in Butler County

$\frac{\text { Range in thickness }}{\text { Feet Inches }}$

Connoquenessing Formation:

Sandstone, massive, light-gray, fine-grained, quartzose; forms cliff _._. _...

Shale; includes thin Quakertown coal _.

Sandstone, or siltstone, massive, fine- to medium-grained; forms cliff . . . . $8-20$

Average thickness, Pottsville Group 170

\section{QUAKERTOWN GOAL}

The Quakertown coal, named by White (1880, p. 65) from exposures at Quakertown Falls, Lawrence County, is in the middle of the Connoquenessing Formation. Except for the few inches of coal exposed in Bear Creek in the east-central part of Butler County, no other exposures of the Quakertown were noted in the county.

MERGER COALS

In counties to the west, three coal beds are normally associated with two thin marine limestone beds near the center of the Mercer Formation. These coal beds are known as the Lower, Middle, and Upper Mercer coals. Except for the two thin coal beds exposed on Bear Creek, no exposures of Mercer coals were noted in Butler County.

\section{HOMEWOOD GOAL}

A coal bed generally occurs just below the main bed of sandstone in the Homewood Formation, but the pattern of distribution of this coal is irregular. Thin sandstone assigned to the Homewood Formation crops out in deeper valleys in the northern part of the county. No outcrop of the Homewood coal was seen at any exposure of this sandstone; however, a thin coal bed is believed to be present at this horizon at most places in the county.

\section{ALLEGHENY GROUP}

The name Allegheny was first used by Rogers (1840, p. 150) for all rocks cropping out along the Allegheny River between Pittsburgh and Warren, Pa. Subsequently, Stevenson (1873, p. 16) defined the Allegheny as a sequence of beds between the top of the Pottsville Formation and the base of the Mahoning Sandstone, and this usage has been followed by most writers. In this report, Allegheny refers to the sequence between the base of the underclay of the Brookville(?) coal and the top of the Upper Freeport coal. This usage accords very closely with Stevenson's definition. 
The Allegheny Group in Butler County is about 280 feet thick. It is at or near the surface in much of the northern half of the county and contains the thickest and best coal beds in the county.

The Allegheny Group is divided, from oldest to youngest, into the Clarion Formation, Vanport Limestone, and the Kittanning and Freeport Formations. These, in turn, are divided into several named and unnamed members (Poth, 1963, p. 28). These units are described in the accompanying generalized section. The discussion that follows is confined to the named units, which have correlative and diagnostic value, and to the associated coal beds.

\section{Generalized section of the Allegheny Group in Butler County}

Allegheny Group:

Freeport Formation:

Range in thickness

Coal, Upper Freeport

Feet Inches

Underclay

0-2

Shale and siltstone

7-10

Shale, fresh-water limestone, and massive sandstone in overlapping lenses (Butler Sandstone Member of Ashley, 1926)

Coal, Lower Freeport $13-42+$

Shale, fresh-water limestone, clay, and massive sandstone in overlapping lenses.

Kittanning Formation:

Coal, Upper Kittanning

Clay, shale, and sandstone in overlapping lenses...-

Coal, Middle Kittanning

Coal, shale, and siltstone

Sandstone, massive; in overlapping lenses

Shale and siltstone; unit includes thin coal bed

Shale and siltstone, unit includes thin coal bed....-

Clay, shale, thin sandstone beds, and massive sandstone in overlapping lenses. $0-42$

Vanport Limestone:

Limestone, fossiliferous, marine. Thin incrustation of bog iron ore on top Clarion Formation:

Shale and siltstone

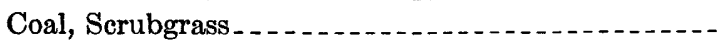

Clay, shale, thin sandstone beds, and massive sandstone............

Coal, Clarion

Shale and thin sandstone bed . .

Coal, Brookville (?)

Underclay

Range in thickness, Allegheny Group 
The Vanport Limestone is the most conspicuous and the most easily identified formation in the Allegheny Group, and for this reason it is used as a marker in mapping coal beds both below and above. The Vanport was named by White $(1878$, p. 60$)$ from exposures near the town of Vanport in Beaver County. The Vanport ranges in thickness from 6 inches to 28 feet. Where it is thick, it consists of several distinct beds individually 1-5 feet thick and is conspicuously fossiliferous (Richardson, 1936, p. 19). Where it is thin, it is argillaceous and commonly has a characteristic cone-in-cone structure. The Vanport Limestone is quarried as a building stone in many places and is produced from a large underground mine at Boyers. In places it is overlain by a thin incrustation of bog iron ore.

The Kittanning and Freeport Formations are named for coal beds contained in them, and these, in turn, were named for their occurrences at the towns of Kittanning and Freeport, on the Allegheny River.

As noted in the generalized section, the Allegheny contains eight coal beds; in ascending order they are: the Brookville(?), Clarion, and Scrubgrass coals, which are below the Vanport Limestone; and the Lower, Middle, and Upper Kittanning coals and the Lower and Upper Freeport coals, which are above the Vanport Limestone.

\section{BROOKVILLE(?) GOAL}

The name Brookville was first used by Rogers $(1858$, p. 475) for a coal bed near the town of Brookville in Jefferson County, Pa. It is not known to which of the several coals near Brookville Rogers intended the name to be applied. A coal in that area that W. G. Platt (1881, p. 106) later designated as the Brookville was later correlated by Graeber and Foose (1942, p. 50-61) with a coal bed in the Clarion Formation. As used in this report, the Brookville(?) coal is stratigraphically the first coal bed above the main sandstone of the Homewood Formation. At most places in Butler County, the Brookville( ?) is 20-50 feet below the Vanport Limestone, although locally it may exceed this range. It crops out in the Parker quadrangle along Bear Creek in Parker Township, and a coal believed to be the Brookville(?) is strip mined in the West Sunbury quadrangle southwest of Annandale, Cherry Township. The coal in these areas has an average thickness of 28 inches and is overlain by shale.

Shaw, Lines, and Munn (1911, p. 6) described a Craigsville coal bed above the Brookville coal. They considered the Brookville to be about 120 feet below the Vanport Limestone. Renick (1924) measured a series of stratigraphic sections on a line starting in the Beaver River valley, extending across the Allegheny River valley, and ending in Clarion County. He concluded that the Craigsville coal of Shaw, 
Lines, and Munn was one of the coal beds in the Mercer Formation. Sherrill and Matteson (1939) also stated that the "Brookville" of Shaw, Lines, and Munn was probably a Mercer coal.

\section{GLARION GOAL}

The Clarion coal crops out in northern Butler County. It is more than 42 inches thick in parts of the Eau Claire, Barkeyville, and Hilliards quadrangles, and in these areas it has been mined extensively by underground methods. In other areas it is strip mined in conjunction with quarrying of the overlying Vanport Limestone. In the vicinity of Boyers east of Eau Claire, and from Hilliards north to Murrinville, the Brookville and Scrubgrass coal beds merge with the Clarion. This tripartite bed, here considered to be the Clarion, was worked at many large mines that are now abandoned.

The Clarion coal is not exposed in the central and southern parts of the county, and less information is available concerning its southern continuity and thickness. In the early 1900 's, the Clarion was reportedly worked at a single underground mine northeast of the city of Butler. At West Winfield in southeastern Butler County, Butts (1906, p. 46) reported that the Clarion was 28-37 inches thick but that it was split into several benches by shale partings. At Buffalo Mills to the northeast in Armstrong County, he reported that an outcrop of Clarion was several feet thick and split into four benches by partings.

\section{SCRUBGRASS COAL}

The Scrubgrass coal is a thin, lenticular coal that is generally about 6 feet below the Vanport Limestone. Outcrops are confined to the northern part of Butler County (Parker, Allegheny, Venango, Cherry, Mercer, Washington, and Slippery Rock Townships). Throughout the rest of the county, the Scrubgrass coal is not exposed. In the Barkeyville, Emlenton, and Parker quadrangles (Marion, Allegheny, and Parker Townships) it is more than 28 inches thick and is strip mined with the underlying Clarion coal. In the area of Boyers (Annandale station), the Scrubgrass coal merges with the Brookville and Clarion coals to form a single bed. In the Emlenton quadrangle (Allegheny Township) about 1 mile northeast of Bonus, the Vanport Limestone is underlain by 10 feet of shale containing fossiliferous concretions, below which are two thick coal beds separated by 15 feet of shale. The upper bed is as much as 3 feet 8 inches thick. In Clarion County, to the east, these beds are known as the Lower and Upper Clarion coals. Richardson (1936, p. 32) listed the Scrubgrass as the Upper Clarion. Shaw, Lines, and Munn (1911, p. 13), however, stated that the Upper 
Clarion coal is probably a split of the Lower Clarion. The first of several thick sandstone beds below the Vanport is about 80 feet below these two coal beds; hence, the upper bed is believed to be the Scrubgrass and the lower the Clarion. At Goff's station near Boyers, the Scrubgrass may be represented only as the upper $2 \frac{1}{2}$ inches of bony coal. At Evans City, Evans City quadrangle (Jackson Township), Richardson (1936, p. 32) cited drill-core records that show the Scrubgrass to range in thickness from 4 feet to 4 feet 10 inches. Elsewhere in the county the coal is believed to be less than 14 inches thick.

\section{KITTANNING COALS}

The Lower, Middle, and Upper Kittanning coals crop out over large areas in western Pennsylvania. In Butler County these coals are readily identified by their position above the Vanport Limestone and below a massive sandstone sequence at the base of the Freeport Formation. The Middle Kittanning bed is one of the thickest and most extensive coal beds in the central and western part of the county and is actively mined at many places.

Lower Kittanning coal.-In Butler County, the Lower Kittanning coal is a few feet to as much as 40 feet above the Vanport Limestone, and 30-50 feet below the Middle Kittanning coal. The Lower Kittanning coal crops out primarily in the northwestern and southeastern parts of the county and has been mined only in a few places. In the northwestern part of the county, it is generally less than 2 feet thick, but in one mine in that area it is more than 32 inches thick. In the southern part of the county, drill-hole records show a coal at depth that Hughes (1933, fig. 51) believed to be the Lower Kittanning. Butts (1904) showed Lower Kittanning coal cropping out east of Winfield and Clearfield Townships, more than 40 inches thick in places, thickening generally to the east. The Lower Kittanning is thin to the southeast in the Mars quadrangle. Near Freedom on Crows Run it is 22 inches thick (Munn, 1911, p. 14). Richardson (1932, p. 42) stated that a coal bed at the approximate position of the Lower Kittanning, 168-203 feet below the Upper Freeport coal, seems to be persistent in the Valencia and Curtisville quadrangles. The Lower Kittanning is present and was mined just west of Zelienople, Beaver County, where it was several feet thick, but it is thin or absent a few miles to the north in Lawrence County. In central Butler County, Richardson regarded the Lower Kittanning as a zone in which the coal is typically thin or absent. The Lower Kittanning is thin or absent in northeastern Butler County in the area of Emlenton.

In summary, the Lower Kittanning seems to thin to the north and to be split into several thin beds or to be absent over much of central 
and northwestern Butler County. Large resources of coal may be present under deep cover in the southern part of the county.

Middle Kittanning coal.-The Middle Kittanning coal is strip mined extensively in north and central Butler County. It may be present at depth in southern Butler County, but data from drill holes are inconclusive; hence the coal is assumed to be less than 14 inches thick in this area (see categories based on thickness of beds, p. C24-C27). Most recent mining of the Middle Kittanning coal is by strip-mining methods, but much underground mining was practiced in the past. The largest of the underground mines, now abandoned, are in the vicinity of Claytonia, Hallston, and Coaltown in the West Sunbury quadrangle (Cherry, Clay, and Brady Townships). In this area, the coal is more than 30 inches thick. There were other large underground mines north of Butler, Pa., near Zelienople, southeast of Portersville, and near Isle, on Muddy Creek. The Middle Kittanning is more than 28 inches thick but less than 42 inches thick over much of northern Butler County. It is the second most valuable bed in the county in terms of original resources in the ground.

Upper Kittanning coal. - The Upper Kittanning coal is relatively thin, fairly persistent, but locally lens shaped. It is $20-50$ feet above the Middle Kittanning coal. The Upper Kittanning is present in many places in the high wall of strip mines where the Middle Kittanning bed is being worked. In other places a thin "rider" coal overlying the Middle Kittanning may be mistaken for the Upper Kittanning. Confusion in use of the name Upper Kittanning results from the fact that the bed is thin and generally not minable; hence, miners often focus attention only on two Kittanning beds, a lower and an upper. Small outliers of Upper Kittanning coal more than 14 inches thick were mapped in the Mt. Chestnut, East Butler, Butler, Saxonburg, Evans City, and Worthington quadrangles (Brady, Franklin, Oakland, Center, Butler, Summit, Winfield, Connoquenessing, and Forward Townships). Northeast of the city of Butler, three large underground mines, now abandoned, were operated in this coal bed. Nowhere was the coal more than 42 inches thick.

In places throughout western Pennsylvania, the Upper Kittanning is a cannel coal. A deposit of cannel coal occurs on the hilltop northeast of the town of Boyers. At this locality the following section was measured :

\begin{tabular}{lccc} 
& \multicolumn{2}{c}{ Thickness } \\
\cline { 2 - 3 } Sheet & Inches \\
Coal, cannel-ate & 15 & \\
Coal, canneloid or cannel shale-- & 1 & 2 \\
Shale & 1 & 1 \\
\hline
\end{tabular}


The coal has pronounced horizontal sheets. Although this deposit is here considered to be the Upper Kittanning bed, its position relative to the Vanport Limestone, about 150 feet below in the valley, and its relation to other beds in the near vicinity suggest that it may be a correlative of the Middle Kittanning bed.

The Upper Kittanning coal is also known locally as the "Pot vein" (Shaw and Munn, 1911, p. 32) because it contains pods or lenses of coal of unusual thickness. One such "pot" was mined in southeast Parker Township, Hilliards quadrangle, about $21 / 2$ miles southeast of North Washington. At this locality, 4 feet 3 inches of a reported 8 feet of coal was measured in an abandoned strip mine. This lens of thick coal is only 23 feet below the Lower Freeport coal and 10 feet below a distinctive bed termed the Lower Freeport limestone. This "pot" is, therefore, more likely a local occurrence unrelated to the Upper Kittanning.

\section{FREEPORT GOALS}

Above the Upper Kittanning coal are two coal beds known as the Lower and Upper Freeport coals. These names are in general use over large areas in western Pennsylvania for two closely spaced coal beds, generally less than 60 feet apart. In Butler County, the Lower and Upper Freeport coals can be identified by their stratigraphic positions above the Upper Kittanning coal and below the massive Mahoning Sandstone Member of the Conemaugh Formation. The two coals are also distinctive in that both are underlain locally by thin fresh-water limestone beds, termed the Lower and Upper Limestone Members by Platt and Platt (1877, p. 316).

Lower Freeport coal.-Although the Lower Freeport coal is widespread in central Butler County and averages more than 28 inches in thickness, its thickness varies greatly, and the coal is of poorer quality than that in other beds; therefore, it is not widely mined. Strip mining is, however, fairly extensive in the Hilliards quadrangle (Washington, Parker, and Concord Townships), where the coal averages 28 inches in thickness. A dark-gray to black, very thin bedded shale commonly overlies the coal and also occurs as partings.

Upper Freeport coal.-The Upper Freeport coal is the uppermost extensively mined coal in Butler County. It crops out in the central and southern parts of the county, but is not exposed in the southwestern part. In the past, the bed was mined extensively by underground methods, but most of the older mines are now abandoned. These mines were developed in several areas, notably near Petrolia, Chicora, and Karns City (Parker quadrangle); southeast of the city of Butler 
(Saxonburg quadrangle); Summit Township, near Jamisonville and Oneida (Mt. Chestnut quadrangle); southeast of Prospect (Evans City quadrangle); Connoquenessing Township and the area near Cunningham (Curtisville quadrangle); and Clinton Township and the area west of Freeport (Freeport quadrangle). In the mined areas the average thickness of the bed was generally more than 28 inches, and locally the bed was almost 5 feet thick. The Upper Freeport coal is exceptionally thick where the bed juts into southeastern Butler County in Clinton and southeastern Middlesex Townships (Freeport and Curtisville quadrangles). In Allegheny and Westmoreland Counties, to the south, Rayburn $(1924$, p. 31) reported that the bed has an average thickness of 7 feet 2 inches. In Butler County, however, only the lower part of this thick bed is minable because the upper part is composed of thin layers of coal intercalated with siltstone, which must be left in the roof.

\section{CONEMAUGH FORMATION}

The name Conemaugh was first applied to deposits of shale and sandstone exposed on the Conemaugh River. Franklin Platt (1875, p. 8) described the Conemaugh as a "series" consisting of the "Mahoning Sandstone" and the overlying "Middle Barren Measures." As used in this report, the Conemaugh Formation is the sequence of beds between the top of the Upper Freeport coal and the base of the underclay of the Pittsburgh coal of the Monongahela Formation. The Conemaugh Formation is as much as 640 feet thick in southern Butler County; however, because of erosion it is thin or absent over most of the northwestern part of the county, and only thin patches are present in the northeastern part.

For purposes of mapping and discussion, the Conemaugh Formation has been divided into several named and unnamed units. For the most part, the named units are either coal beds or associated beds that have value in locating coals or in determining stratigraphic positions within the sequence. The unnamed units are mostly shale and siltstone that are generally poorly exposed and indistinguishable. For this reason, the following discussion is confined primarily to the named units. The Conemaugh Formation contains six coal beds, but these are thin and discontinuous and contain only small resources. The lithology and range in thickness of all units are given in the following generalized section. 
Generalized section of the Conemaugh Formation in Butler County

Morgantown Sandstone Member: Thickness
Feet

Shale, gray-green, sandy, and thin-bedded; also thin-bedded sand-

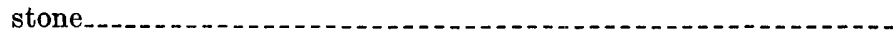

Unnamed unit:

Coal, Wellersburg

$0-1$

Birmingham Shale Member:

Shale, variegated to red, sandy; contains marine fossils.

Unnamed unit:

Coal, Duquesne

Shale, brown

Ames Limestone Member:

Limestone, greenish-gray, siliceous; contains abundant marine fossils . . . . . . .

Coal, Harlem .

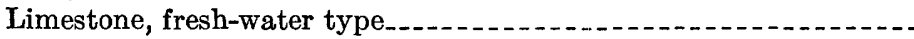

Shale, silty, reddish; in places interbedded with gray shale ("Pittsburgh red beds" of local usage)

Saltsburg Sandstone Member:

Sandstone, massive, lenticular; in places sandy shale and thin-

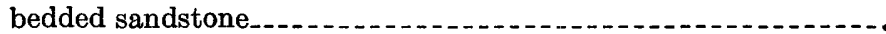

Shale, dark-gray; marine fossils locally abundant. . . . . . . . . .

Coal, Bakerstown

Cambridge Limestone Member:

Limestone, blue-gray, sandy, lenticular

Buffalo Sandstone Member:

Sandstone; variable thickness, massive to thin bedded

Brush Creek Limestone Member:

Limestone; marine fossils locally abundant.

Coal, Brush Creek.

Unnamed unit:

Shale and sandstone

Mahoning Member:

Shale, red (Mahoning Red Bed of Swartz, 1922, p. 55)

Coal, Mahoning -

Limestone, fresh-water type (Mahoning Limestone of White, 1891).

Sandstone, light-yellow-brown, medium- to coarse-grained, crossbedded, massive to thin-bedded.

Maximum total

Of the six coal beds in the Conemaugh Formation, only three-the Mahoning, Brush Creek, and Duquesne coals-contain reportable resources, and together they contribute only a small percentage to the county total.

\section{MAHONING COAL}

The Mahoning coal is less than 14 inches thick in all areas examined, except for a small area in the East Butler quadrangle where it is 28 
inches thick and local lenses about 18 inches thick south of the city of Butler where it was strip mined with the Upper Freeport coal bed. It is also more than 14 inches thick on several hilltops near Portersville, in the Portersville quadrangle.

\section{BRUSH CREEK COAL}

The Brush Creek coal is more than 14 inches but less than 28 inches thick in a few small lenses in East Butler, Worthington, Evans City, Mars, and Baden quadrangles.

\section{BAKERSTOWN GOAL}

The Bakerstown coal is a thin coal that crops out in southern Butler County, specifically near Bakerstown, in Richland Township. According to White $(1878$, p. 162), who named and defined the bed, it is about 2 feet thick. A dark-gray to black fossiliferous marine shale overlies the Bakerstown coal and aids in identifying it. Where observed by the writers, the coal is thin and lenticular.

\section{HARLEM GOAL}

The Harlem coal crops out just below the Ames Limestone Member and is thin and lenticular. Its chief value is as a marker bed in the stratigraphic sequence.

\section{DUQUESNE GOAL}

The Duquesne coal occurs throughout southern Butler County, but it is generally less than 14 inches thick. It is more than 14 inches thick only in an area south of Butler County in the Emsworth quadrangle, where a small mine has been opened in coal slightly more than 28 inches thick.

WELLERSBURG COAL

The Wellersburg coal is the highest coal noted in the Conemaugh Formation. It crops out locally on hills in the southern part of Butler County. It is generally less than 1 foot thick in all exposures examined and is not shown on the geologic map (pl.1).

\section{QUATERNARY DEPOSITS}

The Pennsylvanian rocks of northwestern Butler County are overlain disconformably by unconsolidated glacial drift and terrace deposits of Quaternary age. In the northern part of the county, large areas are covered by glacial-lake and outwash deposits (Preston, 1950). Holocene alluvium covers the bottoms of many of the major 
streams. The geologic map (p. 1) shows only the outer limit of thick glacial deposits that definitely conceal the older rocks. A map of northwestern Pennslyvania showing the boundaries of all glacial deposits, including thinner and isolated deposits, has been prepared by Shepps (in Shepps and others, 1959). A sequence of glacial deposits about 80 feet thick is exposed in a sand and gravel quarry in northeastern Worth Township, north of Kelly School, on the south side of Slippery Rock Creek. In this exposure, the lowermost 60 feet is composed of sand, overlain by about 20 feet of glacial cobbles and pebbles, most of which are of igneous origin. There is an esker in a valley between Jacksville in Worth Township and West Liberty in Brady Township. Most of the glacial material in the county is less than 20 feet thick.

\section{STRUCTURE}

The rocks in Butler County dip gently southward toward the Pittsburgh-Huntington basin, which was described by Richardson (1932). There are no major faults or displacements. The general southward dip is interrupted locally by several broad gentle northeast-trending folds (see fig. 2).

The Amity anticline, the southernmost of these folds, has a maximum amplitude of less than 100 feet. Its axis crosses the extreme southeastern corner of the county in Buffalo Township.

The McMurry syncline has an amplitude of several hundred feet. Its axis crosses Buffalo Township from the southwest corner to the northeast corner. Outcrops of the Conemaugh Formation, including beds as young as the Ames Limestone Member, are preserved in an area of several square miles along the axis.

The Kellersburg anticline has an amplitude of about 200 feet. Its axis crosses Clinton, Buffalo, and Winfield Townships from the southwest part of Clinton to the northeast corner of Winfield. The chief effect of this structure on the geology of these townships is to expose the Upper Freeport coal bed in several of the deeper stream valleys, notably in Cherry Valley, Lardentown, and Starver Runs, in southern Clinton Township, and to raise the Vanport Limestone to stream level at West Winfield in the northeast corner of Winfield Township.

The Bradys Bend syncline has an amplitude of about 100 feet. Its axis enters the county in southeast Middlesex Township and passes through the southeast corner of Penn Township, then through Jefferson, Summit, Clearfield, and Donegal Townships. In Middlesex Township, a thick sequence of beds in the Conemaugh Formation, including extensive areas of Ames Limestone Member, is preserved along the axis 


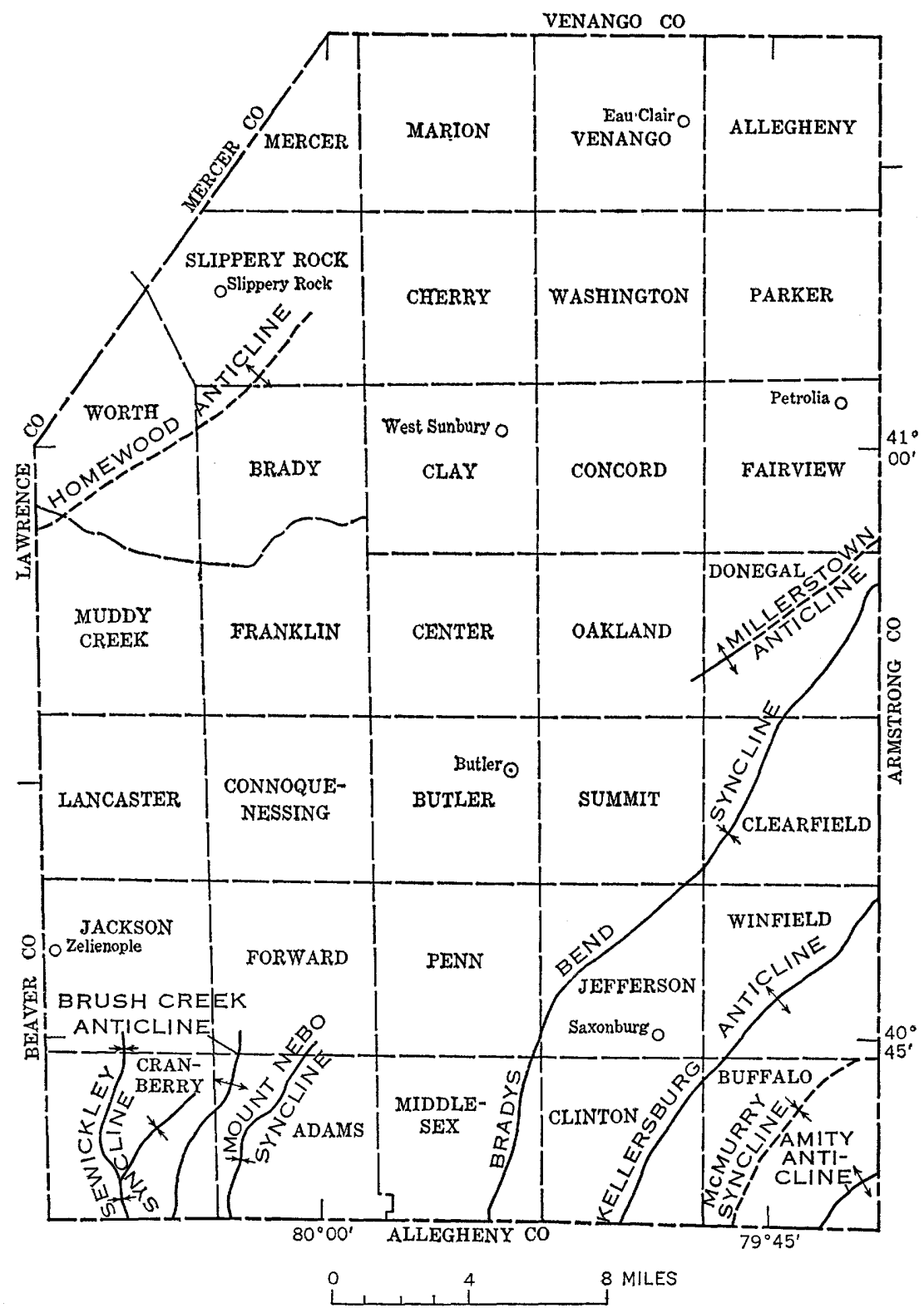

FIGURE 2.-Townships and major structural axes in Butler County. Axes dashed where inferred.

of the syncline. In Clearfield Township, the axis passes near the town of Fennelton. Here the Upper Freeport coal bed is 50-100 feet lower than elsewhere in the vicinity.

The Millerstown anticline has an amplitude of about 50 feet. Where 
the axis crosses Donegal Township, the Upper Freeport coal is $20-40$ feet higher than it is in nearby areas.

The Sewickley syncline, Brush Creek anticline, and Mount Nebo syncline are in Cranberry and Adams Townships. The amplitude of each is less than 50 feet.

The axis of the Homewood anticline extends from northwest Muddy Creek Township to southern Slippery Rock Township. The chief effect of this structure on the local geology has been to raise the Lower and Middle Kittanning coals 20-50 feet and possibly to restrict the course of Wolf Creek and Slippery Rock Creek, thus preserving from erosion a large area of coal in the lower part of the Allegheny Group.

Throughout the rest of the county, small folds of low amplitude, such as the Brush Creek anticline and Mt. Nebo syncline, are locally present, but they have little influence on the geology.

\section{COAL RESOURCES}

As here estimated, the original resources of coal in Butler County totaled $3,677.80$ million tons, of which 646.79 million tons is classified as measured, 1,467.14 million tons as indicated, and 1,563.87 million tons as inferred (see p. C28). Included in the 646.79 million tons of measured resources is about 222 million tons of coal mined or lost in mining; the remaining measured resources are about 425 million tons, as of January 1,1966.

The remaining measured resources of about 425 million tons plus the indicated and inferred resources of about 3,031 million tons give a total remaining resource of about 3,456 million tons, and the estimated recoverable resources as of that date totaled 1,883 million tons.

The distribution of these resources by beds, by thickness of coal, by thickness of overburden, and by categories according to reliability of the estimates, is shown in tables 1-3. The quadrangle areas used for breakdown of the resource data are shown in figure 3. The outcrops, mined areas, and regional variations in thickness of individual beds are shown on plate 3 .

The resources are contained in 11 beds but are largely concentrated in the Upper and Lower Freeport, Middle and Lower Kittanning, and Clarion beds as shown below :

Estimated original coal resources in Butler County, by beds, in order of decreasing abundance

\begin{tabular}{|c|c|c|c|c|}
\hline & a millions & short tons] & & \\
\hline Bed & Tonnage & & Bed & Tonnage \\
\hline iddle Kittanning & $\begin{array}{l}910 \\
902\end{array}$ & Brush Creek. & & $\begin{array}{l}41 \\
11\end{array}$ \\
\hline Lower Freeport & 635 & Brookville_.. & & 11 \\
\hline & 590 & Mahoning ... & & \\
\hline $\begin{array}{l}\text { Clarion } \\
\text { Upper Kittanning }\end{array}$ & 474 & Duquesne_. & & \\
\hline
\end{tabular}


TABLE 1.-Estimated original coal resources of Butler County under less than 60 feet of overburden, by quadrangles and by beds [In millions of short tons. Quadrangle areas shown in fig. 3]

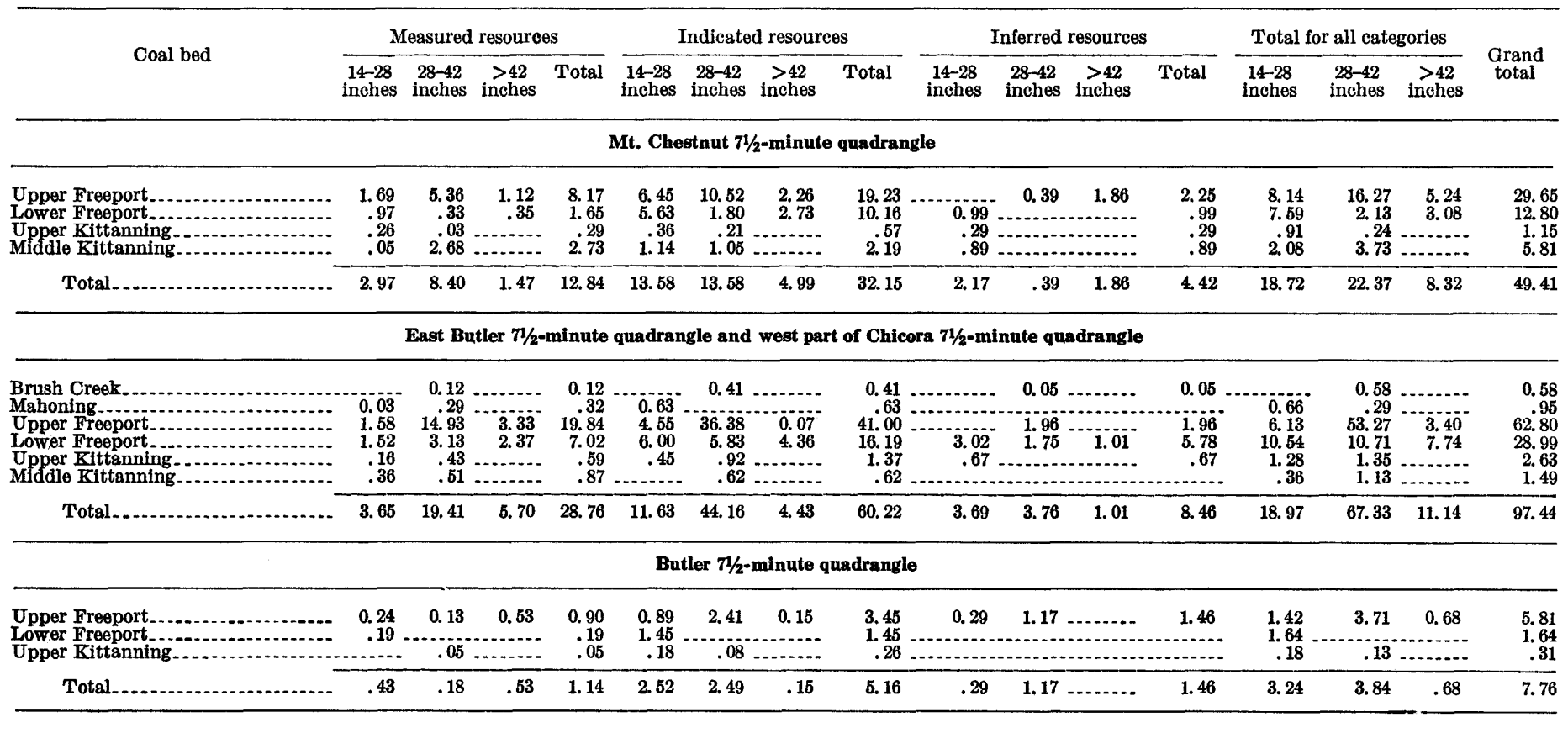


Mahoning -

\begin{tabular}{|c|c|c|c|c|c|c|c|c|c|c|c|c|c|}
\hline $\begin{array}{r}0.12 \\
.93 \\
1.00 \\
.37\end{array}$ & $\begin{array}{l}5.61 \\
.31 \\
.21\end{array}$ & $\begin{array}{r}0.52 \\
.50 \\
\end{array}$ & $\begin{array}{r}0.12 \\
7.06 \\
1.81 \\
.58\end{array}$ & $\begin{array}{r}0.06 \\
4.70 \\
2.56 \\
.54\end{array}$ & $\begin{array}{r}7.02 \\
.53 \\
\end{array}$ & 1.16 & $\begin{array}{r}0.06 \\
11.72 \\
4.25 \\
.54\end{array}$ & $\begin{array}{l}0.24 \\
1.37 \\
1.32\end{array}$ & $\begin{array}{l}0.24 \\
.37 \\
1.32\end{array}$ & $\begin{array}{l}0.18 \\
5.87 \\
\text { 3. } 93 \\
2.23\end{array}$ & $\begin{array}{r}12.63 \\
.84 \\
.21\end{array}$ & $\begin{array}{l}0.52 \\
1.66\end{array}$ & $\begin{array}{r}0.18 \\
19.02 \\
6.43 \\
2.44\end{array}$ \\
\hline 2.42 & 6.13 & 1.02 & 9.57 & 7.86 & 7.55 & 1.16 & 16. 57 & 1.93 & 1.93 & 12. 21 & 13. 68 & 2.18 & \\
\hline
\end{tabular}

Hilliards, west part of Parker, south part of Eau Clair, and south west corner of Emlenton $71 / 2$-minute quadrangles

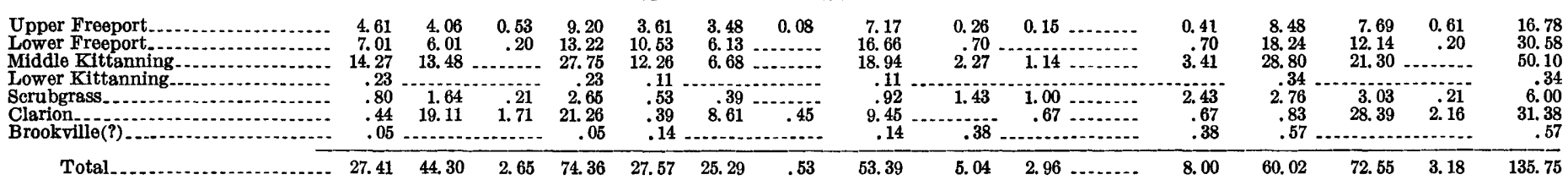

West Sunbury $71 / 2$-minute quadrangle and south part of Barkeyville $71 / 2$-minute quadrangle

\begin{tabular}{|c|c|c|c|c|c|c|c|c|c|c|c|c|c|c|}
\hline $\begin{array}{l}\text { Upper Freeport } \\
\text { Lower Freeport } \\
\text { Middle Kittanning } \\
\text { Lower Kittanning- } \\
\text { Scrubgrass_.. } \\
\text { Clarion } \\
\text { Brookville(?) }\end{array}$ & $\begin{array}{r}0.26 \\
6.31 \\
.17 \\
.08 \\
4.99 \\
.49\end{array}$ & $\begin{array}{r}0.71 \\
1.47 \\
19.85 \\
8.68 \\
8.51 \\
.69\end{array}$ & 39 & $\begin{array}{r}0.71 \\
2.34 \\
26.16 \\
.17 \\
.76 \\
13.89 \\
1.18\end{array}$ & $\begin{array}{r}0.39 \\
3.98 \\
.19 \\
5.20 \\
.38\end{array}$ & $\begin{array}{r}0.21 \\
2.77 \\
2.01 \\
.56 \\
6.23 \\
.18 \\
18\end{array}$ & $\begin{array}{r}0.21 \\
3.16 \\
3.98 \\
2.20 \\
.56 \\
11.43 \\
.56\end{array}$ & $\begin{array}{r}0.12 \\
.60 \\
1.95 \\
.49\end{array}$ & $\begin{array}{r}0.51 \\
.15\end{array}$ & $\begin{array}{c}0.12 \\
1.11 \\
2.10 \\
.49\end{array}$ & $\begin{array}{r}0.65 \\
10.41 \\
.36 \\
.68 \\
12.14 \\
1.36\end{array}$ & $\begin{array}{r}0.92 \\
4.24 \\
19.85 \\
2.01 \\
1.75 \\
14.89 \\
.87\end{array}$ & 0.61 & $\begin{array}{r}0.92 \\
5.50 \\
30.26 \\
2.37 \\
2.43 \\
27.42 \\
2.23\end{array}$ \\
\hline Total _. & 30 & 31.91 & 1.00 & 45. 21 & 10.14 & 11.96 & 22.10 & 3. 16 & .66 & 3.82 & 25.60 & 44.53 & 1.00 & 71.13 \\
\hline
\end{tabular}

Slippery Rock, southeast corner of Grove City, and southeast corner of Harlansburg $71 / 2$-minute quadrangles

\begin{tabular}{|c|c|c|c|c|c|c|c|c|c|c|c|}
\hline \multicolumn{12}{|c|}{ Slippery Rock, southeast corner of Grove City, and southeast corner of Harlansburg $71 / 2$-minute quadrangles } \\
\hline $\begin{array}{l}\text { Upper Freeport. } \\
\text { Lower Freeport } \\
\text { Middle Kittanning } \\
\text { Lower Kittanning } \\
\text { Clarion. }\end{array}$ & $\begin{array}{l}0.11 \\
.23 \\
3.19 \\
1.52 \\
.61\end{array}$ & $\begin{array}{r}0.07 \\
12.80 \\
.35 \\
35\end{array}$ & $\begin{array}{r}0.11 \\
.30 \\
15.99 \\
1.87 \\
.61\end{array}$ & $\begin{array}{r}0.02 \\
.14 \\
.85 \\
7.29 \\
3.29\end{array}$ & 1.92 & $\begin{array}{l}0.02 \\
.23 \\
2.77 \\
7.29 \\
3.29\end{array}$ & 4.11 & 4.11 & $\begin{array}{r}0.13 \\
.37 \\
4.04 \\
12.92 \\
5.02\end{array}$ & $\begin{array}{r}0.16 \\
14.72 \\
.35\end{array}$ & $\begin{array}{r}0.13 \\
.53 \\
18.76 \\
13.27 \\
5.02\end{array}$ \\
\hline Total. . & 5. 66 & $13.22 \ldots$ & 18.88 & 11. 59 & 2.01 & 13. 60 & 5. 23 & 5. 23 & 22.48 & 15. 23 & 37. 71 \\
\hline
\end{tabular}


$\mathrm{T}_{\mathrm{ABLE}}$ 1.-Estimated original coal resources of Butler County under less than 60 feet of overburden, by quadrangles and by beds-Continued

\begin{tabular}{|c|c|c|c|c|c|c|c|c|c|c|c|c|c|c|c|}
\hline \multirow{2}{*}{ Coal bed } & \multicolumn{3}{|c|}{ Measured resources } & \multicolumn{4}{|c|}{ Indicated resources } & \multicolumn{4}{|c|}{ Inferred resources } & \multicolumn{3}{|c|}{ Total for all categories } & \multirow{2}{*}{$\begin{array}{l}\text { Grand } \\
\text { total }\end{array}$} \\
\hline & $\begin{array}{l}\text { 14-28 } 28-42 \\
\text { inches inches }\end{array}$ & $\underset{\text { inches }}{>42}$ & Total & $\begin{array}{l}14-28 \\
\text { inches }\end{array}$ & $\begin{array}{l}28-42 \\
\text { inches }\end{array}$ & $\underset{\text { inches }}{>42}$ & Total & $\begin{array}{l}\text { 14-28 } \\
\text { inches }\end{array}$ & $\begin{array}{l}28-42 \\
\text { inches }\end{array}$ & $\underset{\text { inches }}{>42}$ & Total & $\begin{array}{l}\text { 14-28 } \\
\text { inches }\end{array}$ & $\begin{array}{c}28-42 \\
\text { inches }\end{array}$ & $\underset{\text { inches }}{>42}$ & \\
\hline
\end{tabular}

Valencia $71 / 2$-minute quadrangle

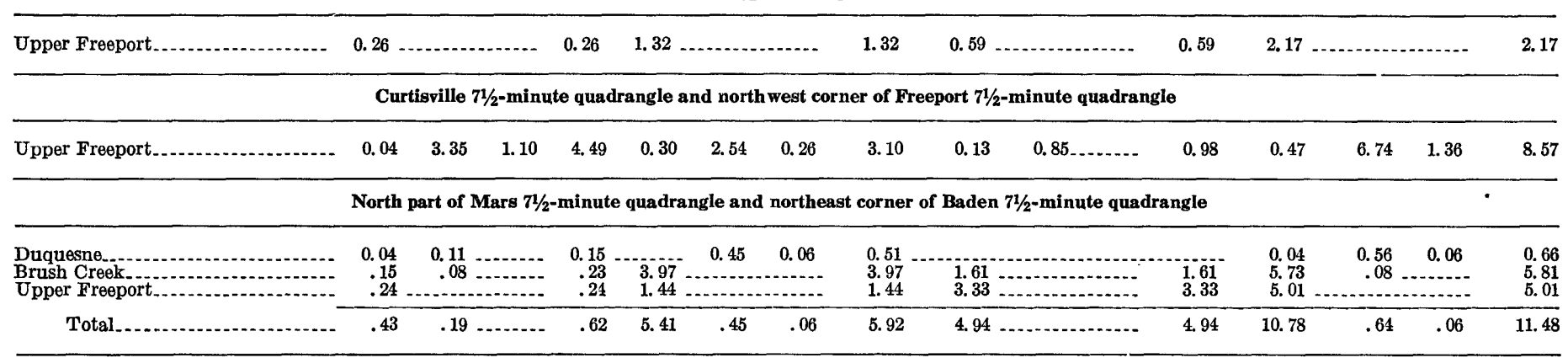

Prospect 71/2-minute quadrangle and east part of Portersville $71 / 2$-minute quadrangle

\begin{tabular}{|c|c|c|c|c|c|c|c|c|c|c|c|c|c|c|c|}
\hline $\begin{array}{l}\text { Mahoning } \\
\text { Upper Freeport } \\
\text { Lower Freeport } \\
\text { Middle Kittanning }\end{array}$ & $\begin{array}{l}0.11 \\
.99 \\
1.80 \\
2.95\end{array}$ & $\begin{array}{r}0.76 \\
17.72\end{array}$ & 0.73 & $\begin{array}{r}0.11 \\
.99 \\
3.29 \\
22.28\end{array}$ & $\begin{array}{r}7.53 \\
10.08 \\
6.10\end{array}$ & $\begin{array}{l}0.27 \\
3.25 \\
2.55\end{array}$ & 0.16 & $\begin{array}{r}7.80 \\
13.49 \\
8.65\end{array}$ & $\begin{array}{l}5.07 \\
2.16 \\
1.30\end{array}$ & 0.11 & $\begin{array}{l}5.07 \\
3.16 \\
1.41\end{array}$ & $\begin{array}{r}0.11 \\
13.59 \\
14.04 \\
10.35\end{array}$ & $\begin{array}{r}0.27 \\
4.01 \\
20.38\end{array}$ & 0.89 & $\begin{array}{r}0.11 \\
13.86 \\
18.94 \\
32.34\end{array}$ \\
\hline Total & 5.85 & 18. 48 & 2.34 & 26.67 & 23. 71 & 6. 07 & .16 & 29.94 & 8.53 & $.11 \ldots \ldots$ & 8.64 & 38.09 & 24.66 & 2.50 & 65.25 \\
\hline
\end{tabular}


Evans City 71/2-minute quadrangle and east part of Zelienople 71/2-minute quadrangle

\begin{tabular}{|c|c|c|c|c|c|c|c|c|c|c|c|c|c|c|c|}
\hline $\begin{array}{l}\text { Brush Creek. } \\
\text { Upper Freeport. } \\
\text { Lower Freeport } \\
\text { Upper Kittanning } \\
\text { Middle Kittanning }\end{array}$ & $\begin{array}{l}0.19 \\
1.54 \\
1.71 \\
.08 \\
1.61\end{array}$ & $\begin{array}{r}0.66 \\
.32 \\
.49 \\
4.08\end{array}$ & $\begin{array}{c}0.36 \\
\end{array}$ & $\begin{array}{r}0.19 \\
2.56 \\
2.03 \\
.57 \\
5.69\end{array}$ & $\begin{array}{l}0.32 \\
7.58 \\
9.06 \\
.45 \\
4.25\end{array}$ & $\begin{array}{l}2.64 \\
.16 \\
2.09 \\
6.19\end{array}$ & 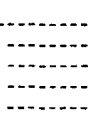 & $\begin{array}{r}0.32 \\
10.22 \\
9.22 \\
2.54 \\
10.44\end{array}$ & $\begin{array}{r}4.40 \\
.59 \\
1.67 \\
.05\end{array}$ & 1. 18 . 01 & $\begin{array}{l}5.15 \\
.59 \\
2.85 \\
1.06\end{array}$ & $\begin{array}{r}0.51 \\
13.52 \\
11.36 \\
2.20 \\
5.91\end{array}$ & $\begin{array}{r}4.05 \\
.48 \\
3.76 \\
11.28\end{array}$ & 0.36 & $\begin{array}{r}0.51 \\
17.93 \\
11.84 \\
5.96 \\
17.19\end{array}$ \\
\hline Total & 5.13 & 5.55 & .36 & 11.04 & 21.66 & 11.08 & $\ldots$ & 32.74 & 6. 71 & $2.94 \ldots$ & 9.65 & 33.50 & 19.57 & .36 & 53.43 \\
\hline Grand total. & 66.55 & 151.12 & 16.17 & 233.84 & 137.29 & 127.18 & 11.74 & 276. 21 & 42.41 & 12.84 & 58.12 & 246.25 & 291.14 & 30.78 & 568.17 \\
\hline
\end{tabular}


TABLE 2.-Estimated original coal resources of Butler County under 60-1,000 feet of overburden, by beds and by quadrangles [In millions of short tons. Quadrangle areas shown on fig. 3]

\begin{tabular}{|c|c|c|c|c|c|c|c|c|c|c|c|c|c|c|c|c|}
\hline \multirow{2}{*}{ Coal bed } & \multicolumn{4}{|c|}{ Measured resources } & \multicolumn{4}{|c|}{ Indicated resources } & \multicolumn{4}{|c|}{ Inferred resources } & \multicolumn{3}{|c|}{ Total for all categories } & \multirow{2}{*}{$\begin{array}{c}\text { Grand } \\
\text { total }\end{array}$} \\
\hline & $\begin{array}{l}\text { 14-28 } \\
\text { inches }\end{array}$ & $\underset{\text { inches }}{28-42}$ & $\underset{\text { inches }}{>42}$ & Total & $\begin{array}{c}\text { 14-28 } \\
\text { inches }\end{array}$ & $\begin{array}{c}28-42 \\
\text { inches }\end{array}$ & $\underset{\text { inches }}{>42}$ & Total & $\begin{array}{l}\text { 14-28 } \\
\text { inches }\end{array}$ & $\begin{array}{c}28-42 \\
\text { inches }\end{array}$ & $\underset{\text { inches }}{>42}$ & Total & $\begin{array}{l}\text { 14-28 } \\
\text { inches }\end{array}$ & $\begin{array}{c}28-42 \\
\text { inches }\end{array}$ & $\underset{\text { inches }}{>42}$ & \\
\hline \multicolumn{17}{|c|}{ Mt. Chestnut $71 / 2$-minute quadrangle } \\
\hline $\begin{array}{l}\text { Upper Freeport } \\
\text { Lower Freeport } \\
\text { Upper Kittanning } \\
\text { Middle Kittanning. }\end{array}$ & $\begin{array}{r}1.90 \\
.97 \\
.19 \\
3.66\end{array}$ & $\begin{array}{r}8.92 \\
.26 \\
\hdashline 14.74\end{array}$ & $\begin{array}{r}0.90 \\
.42 \\
-4 .-- \\
-0 .-1\end{array}$ & $\begin{array}{r}11.72 \\
1.65 \\
1.19 \\
18.40\end{array}$ & $\begin{array}{r}17.86 \\
20.74 \\
1.28 \\
12.75\end{array}$ & $\begin{array}{r}29.98 \\
7.68 \\
.29 \\
28.32\end{array}$ & \begin{tabular}{r}
0.88 \\
4.65 \\
\hdashline$-0 .-$ \\
\end{tabular} & $\begin{array}{r}48.72 \\
33.07 \\
1.57 \\
41.07\end{array}$ & $\begin{array}{r}0.69 \\
17.87 \\
2.35 \\
\mathbf{5 5 . 6 5}\end{array}$ & 6.19 & (n) & $\begin{array}{r}6.88 \\
17.87 \\
2.35 \\
76.82\end{array}$ & $\begin{array}{r}20.45 \\
39.58 \\
3.82 \\
72.06\end{array}$ & $\begin{array}{r}45.09 \\
7.94 \\
.29 \\
64.23\end{array}$ & $\begin{array}{r}1.78 \\
5.07 \\
-0-\end{array}$ & $\begin{array}{r}67.32 \\
52.59 \\
4.11 \\
136.29\end{array}$ \\
\hline Total ......... & 6.72 & 23.92 & 1.32 & 31. 96 & 52.63 & 66.27 & 5. 53 & 124.43 & 76. 56 & 27.36 & & 103.92 & 135.91 & 117.55 & 6.85 & 260.31 \\
\hline \multicolumn{17}{|c|}{ East Butler $71 / 2$-minute quadrangle and west part of Chicora $71 / 2$-minute quadrangles } \\
\hline $\begin{array}{l}\text { Brush Creek- } \\
\text { Mahoning- } \\
\text { Upper Freeportt } \\
\text { Lower Freeport- } \\
\text { Upper Kittanning } \\
\text { Middle Kittanning } \\
\text { Lower Kittanning }\end{array}$ & $\begin{array}{r}0.90 \\
1.23 \\
.85 \\
.09 \\
1.34\end{array}$ & $\begin{array}{r}19.45 \\
2.34 \\
6.64 \\
5.43 \\
\end{array}$ & $\begin{array}{r}2.14 \\
2.37 \\
4.52 \\
\\
\end{array}$ & $\begin{array}{r}22.49 \\
5.94 \\
12.01 \\
5.52 \\
1.34\end{array}$ & $\begin{array}{r}0.01 \\
8.80 \\
28.22 \\
2.06 \\
17.58 \\
21.80 \\
\end{array}$ & $\begin{array}{r}0.08 \\
.08 \\
64.18 \\
42.91 \\
12.79 \\
14.06 \\
\end{array}$ & (22. 55 & $\begin{array}{r}0.08 \\
.09 \\
72.98 \\
93.68 \\
14.85 \\
31.64 \\
21.80\end{array}$ & $\begin{array}{r}40.42 \\
4.80 \\
19.06 \\
23.35 \\
\end{array}$ & $\begin{array}{r}2.27 \\
22.22 \\
-34.76 \\
\end{array}$ & 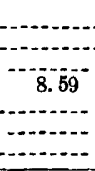 & $\begin{array}{r}2.27 \\
71.23 \\
4.80 \\
73.82 \\
23.35\end{array}$ & $\begin{array}{r}0.01 \\
9.70 \\
69.87 \\
7.71 \\
36.73 \\
46.49 \\
\end{array}$ & $\begin{array}{r}0.08 \\
.08 \\
85.90 \\
67.47 \\
19.43 \\
74.25 \\
\end{array}$ & $\begin{array}{r}2.14 \\
33.51 \\
4.52 \\
-1.5 \\
\end{array}$ & $\begin{array}{r}0.08 \\
.09 \\
97.74 \\
170.85 \\
31.66 \\
110.98 \\
46.49\end{array}$ \\
\hline Total & 4. 41 & 33.86 & 9.03 & 47.30 & 78.47 & 134.10 & 22. 55 & 235.12 & 87.63 & 79.25 & 8. 59 & 175. 47 & 170.51 & 247. 21 & 40.17 & 457.89 \\
\hline \multicolumn{17}{|c|}{ Butler $71 / 2$-minute quadrangle } \\
\hline $\begin{array}{l}\text { Upper Freeport } \\
\text { Lower Freeport } \\
\text { Upper Kittanning } \\
\text { Middle Kittanning } \\
\text { Lower Kittanning }\end{array}$ & $\begin{array}{l}0.28 \\
1.67 \\
2.26\end{array}$ & $\begin{array}{r}0.08 \\
.02 \\
.70\end{array}$ & 0.93 & $\begin{array}{l}1.29 \\
1.67 \\
.02 \\
2.96\end{array}$ & $\begin{array}{r}12.91 \\
30.65 \\
18.77 \\
18.91\end{array}$ & $\begin{array}{r}7.30 \\
.54 \\
1.39\end{array}$ & $\begin{array}{c}2.24 \\
-2 .\end{array}$ & $\begin{array}{r}22.45 \\
30.65 \\
1.31 \\
20.30 \\
\end{array}$ & $\begin{array}{r}16.22 \\
52.80 \\
7.79 \\
16.74 \\
6.20 \\
\end{array}$ & \begin{tabular}{c}
16.49 \\
\hdashline-1. \\
\hdashline
\end{tabular} & . & $\begin{array}{r}32.71 \\
62.80 \\
7.79 \\
16.74 \\
6.20 \\
\end{array}$ & $\begin{array}{r}29.41 \\
85.12 \\
8.56 \\
37.91 \\
6.20 \\
\end{array}$ & $\begin{array}{r}23.87 \\
2.56 \\
2.09\end{array}$ & $\begin{array}{c}3.17 \\
\\
\end{array}$ & $\begin{array}{r}56.45 \\
85.12 \\
9.12 \\
40.00 \\
6.20 \\
\end{array}$ \\
\hline Total $\ldots . . .1$. & 4. 21 & .80 & .93 & 5.94 & 63.24 & 9.23 & 2.24 & $7 \pm .71$ & 99.75 & 16.49 & .......... & 116. 24 & 167.20 & 26.52 & 3.17 & 196.89 \\
\hline
\end{tabular}




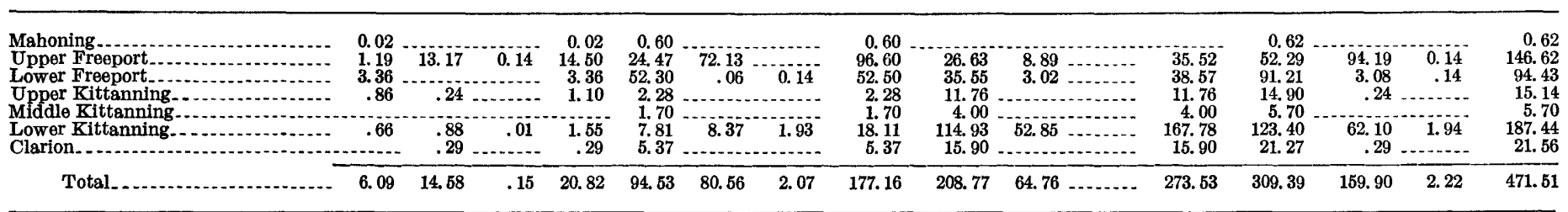

Hilliards, west part of Parker, south part of Eau Clair, and south west corner of Emlenton $71 / 2$-minute quadrangles

\begin{tabular}{|c|c|c|c|c|c|c|c|c|c|c|c|c|c|c|c|}
\hline $\begin{array}{l}\text { Upper Freeport. } \\
\text { Lower Freeport } \\
\text { Middle Kittanning- } \\
\text { Lower Kittanning. } \\
\text { Scrubgrass_..... } \\
\text { Clarion } \\
\text { Brook vilie(?) }\end{array}$ & $\begin{array}{r}2.49 \\
1.33 \\
17.13 \\
.39 \\
1.06 \\
6.06\end{array}$ & $\begin{array}{r}0.71 \\
59 \\
27.18 \\
67.44\end{array}$ & $\begin{array}{c}0.15 \\
16.48\end{array}$ & $\begin{array}{r}3.20 \\
2.07 \\
44.31 \\
.39 \\
1.20 \\
89.98 \\
\end{array}$ & $\begin{array}{r}1.77 \\
6.77 \\
28.35 \\
.07 \\
3.62 \\
112.85 \\
.32\end{array}$ & $\begin{array}{r}2.96 \\
4.36 \\
31.44 \\
3.43 \\
\quad .31\end{array}$ & $\begin{array}{c}0.42 \\
\end{array}$ & $\begin{array}{r}4.73 \\
11.55 \\
59.79 \\
.07 \\
7.05 \\
113.16 \\
.32\end{array}$ & $\begin{array}{r}0.07 \\
.06 \\
8.98 \\
13.62 \\
18.10 \\
2.15\end{array}$ & 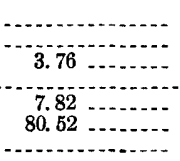 & $\begin{array}{r}0.07 \\
.06 \\
12.74 \\
21.44 \\
98.62 \\
2.15\end{array}$ & $\begin{array}{r}4.33 \\
8.16 \\
54.46 \\
.46 \\
18.30 \\
137.01 \\
2.47\end{array}$ & $\begin{array}{r}3.67 \\
4.95 \\
62.38\end{array}$ & $\begin{array}{c}0.57 \\
16.48 \\
\end{array}$ & $\begin{array}{r}8.00 \\
13.68 \\
116.84 \\
.46 \\
29.69 \\
301.76 \\
2.47\end{array}$ \\
\hline Total. & 28.46 & 96.06 & 16. 63 & 141.15 & 153.75 & 42.50 & .42 & 196.67 & 42.98 & 92.10 & 135.08 & 225.19 & 230.66 & 17.05 & 472.90 \\
\hline
\end{tabular}

West Sunbury 71/2-minute quadrangle and south part of Barkeyville $71 / 2$-minute quadrangle

\begin{tabular}{|c|c|c|c|c|c|c|c|c|c|c|c|c|c|c|}
\hline Upper Freeport & & 0.07 & & 0.07 & & & & & & & & 0.07 & & 0.07 \\
\hline Lower Freeport & & & & & 0.08 & 1.95 & 2. 03 & & & & 0.08 & 1.95 & & 2.03 \\
\hline Middle Kittanning & 5.82 & 21.10 & ........ & 26.92 & 5. 56 & .08 & 5.64 & 0.35 & 0.18 & 0.53 & 11.73 & 21.36 & ....... & 33.09 \\
\hline Lower Kittanning & .59 & & -.-.-..- & .87 & $\begin{array}{r}.59 \\
96\end{array}$ & 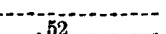 & $\begin{array}{r}.59 \\
1.48\end{array}$ & .07 & $-44^{2}$ & $\stackrel{.07}{1.08}$ & $\begin{array}{l}1.25 \\
1.60\end{array}$ & .28 & & $\begin{array}{l}1.53 \\
2.56\end{array}$ \\
\hline Clarion & 4.98 & 21.04 & 5.08 & 31.10 & 18. 51 & $11,67, \ldots$ & 30.18 & 11. 54 & 1.09 & 12.63 & 35. 03 & 33.80 & 5.08 & 73.91 \\
\hline Brookville(?) & .09 & .36 & ....... & .45 & .77 & 1.71 & 2.48 & 2.42 & 19 & 2.61 & 3.28 & 2.26 & -.....- & 5.54 \\
\hline Total_.. & 11.48 & 42.85 & 5. 08 & 59.41 & 26.47 & 15.93 & 42.40 & 15.02 & 1.90 & 16.92 & 52.97 & 60.68 & 5.08 & 118.73 \\
\hline
\end{tabular}


TABLE 2.-Estimated original coal resources of Butler County under 60-1,000 feet of overburden, by beds and by quadrangles-Continued

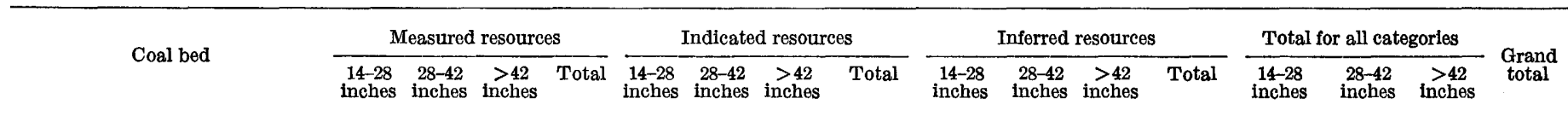

Slippery Rock, southeast corner of Grove City, and southeast corner of Harlansburg $71 / 2$-minute quadrangles

\begin{tabular}{|c|c|c|c|c|c|c|c|c|c|c|c|c|c|}
\hline $\begin{array}{l}\text { Upper Freeport.... } \\
\text { Lower Freeport } \\
\text { Upper Kittanning } \\
\text { Middle Kittanning } \\
\text { Lower Kittanning } \\
\text { Clarion }\end{array}$ & $\begin{array}{l}0.05 \\
.56 \\
.55-\end{array}$ & $\begin{array}{l}0.07 \\
5.54 \\
-0 .\end{array}$ & 0.32 & $\begin{array}{r}0.05 \\
.32 \\
.07 \\
5.54 \\
.56 \\
.55\end{array}$ & $\begin{array}{l}1.20 \\
.04 \\
9.30 \\
6.90\end{array}$ & 0.71 & $\begin{array}{l}1.20 \\
.75 \\
9.30 \\
6.90\end{array}$ & $\begin{array}{r}1.11 \\
4.42 \\
5.92\end{array}$ & 0.18 & $\begin{array}{l}4.11 \\
5.90 \\
5.92\end{array}$ & $\begin{array}{r}0.05 \\
2.31 \\
14.04 \\
13.37\end{array}$ & 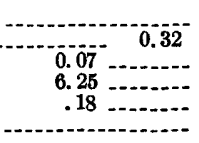 & $\begin{array}{r}0.05 \\
.32 \\
2.38 \\
6.29 \\
14.46 \\
13.37\end{array}$ \\
\hline Total & 1.16 & 5.61 & .32 & 7.09 & 17.44 & .71 & 18.15 & 11.45 & .18 & 11.63 & 30.05 & 6.50 & 36.87 \\
\hline \multicolumn{14}{|c|}{ Valencia $71 / 2$-minute quadrangle } \\
\hline $\begin{array}{l}\text { Upper Freeport } \\
\text { Lower Freeport } \\
\text { Lower Kittanning }\end{array}$ & 0.28 & & $\ldots$ & 0.28 & 6.93 & (n) & \begin{tabular}{c}
6.93 \\
\hdashline-2
\end{tabular} & $\begin{array}{r}59.47 \\
3.54 \\
46.85\end{array}$ & $0.77-10$ & $\begin{array}{r}60.24 \\
3.54 \\
46.85\end{array}$ & $\begin{array}{r}66.68 \\
3.54 \\
46.85\end{array}$ & 0.77 & $\begin{array}{r}67.45 \\
3.54 \\
46.85\end{array}$ \\
\hline Total & .28 & -....- & 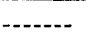 & .28 & 6.93 & 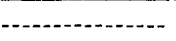 & 6.93 & 109.86 & $.77 \ldots \ldots$ & 110.63 & 117.07 & $.77 \ldots$ & 117.84 \\
\hline \multicolumn{14}{|c|}{ Curtisville $71 / 2$-minute quadrangle and south west corner of Freeport $71 / 2$-minute quadrangle } \\
\hline $\begin{array}{l}\text { Upper Freeport } \\
\text { Lower Freeport } \\
\text { Lower Kittanning }\end{array}$ & 0.16 & 14.32 & 11.60 & 26.08 & 9.08 & 3.27 & \begin{tabular}{ll}
62.34 \\
\hdashline-1.2
\end{tabular} & $\begin{array}{r}30.52 \\
3.08 \\
154.35\end{array}$ & 28.27 & $\begin{array}{r}58.79 \\
3.08 \\
154.35\end{array}$ & $\begin{array}{r}39.76 \\
3.08 \\
154.35\end{array}$ & $\begin{array}{c}92.58 \quad 14.87 \\
\\
\end{array}$ & $\begin{array}{r}147.21 \\
3.08 \\
154.35\end{array}$ \\
\hline Total $\ldots$ & .16 & 14.32 & 11.60 & 26.08 & 9.08 & 49.99 & 62.34 & 187.95 & $28.27 \ldots \ldots$ & 216.22 & 197.19 & 92.58 & 304.64 \\
\hline
\end{tabular}




\begin{tabular}{|c|c|c|c|c|c|c|c|c|c|c|c|c|}
\hline $\begin{array}{l}\text { Duquesne } \\
\text { Brush Creek } \\
\text { Upper Freeport } \\
\text { Middle Kittanning. } \\
\text { Lower Kittanning }\end{array}$ & 0.14 & 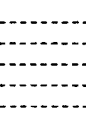 & - & 0.14 & $\begin{array}{l}0.05 \\
2.35 \\
2.56 \\
3.12\end{array}$ & (n) & $\begin{array}{l}0.05 \\
2.35 \\
2.56 \\
3.12\end{array}$ & $\begin{array}{r}1.88 \\
65.53 \\
9.26 \\
50.90\end{array}$ & $\begin{array}{r}1.88 \\
65.53 \\
9.26 \\
50.90\end{array}$ & $\begin{array}{r}0.05 \\
4.23 \\
68.09 \\
12.52 \\
50.90\end{array}$ & (2) & $\begin{array}{r}0.05 \\
4.23 \\
68.09 \\
12.52 \\
50.90\end{array}$ \\
\hline Total & .14 & (n) & 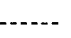 & .14 & 8.08 & - & 8.08 & $127.57 \quad \ldots$ & 127.57 & 135. 79 & (n.... & 135. 79 \\
\hline \multicolumn{13}{|c|}{ Prospect $71 / 2$-minute quadrangle and east part of Portersville $71 / 2$-minute quadrangle } \\
\hline $\begin{array}{l}\text { Upper Freeport } \\
\text { Lower Freeport } \\
\text { Middle Kittanning } \\
\text { Lower Kittanning }\end{array}$ & $\begin{array}{l}0.40 \\
1.16 \\
5.81\end{array}$ & $\begin{array}{r}0.98 \\
32.08\end{array}$ & $\begin{array}{l}0.40 \\
2.74\end{array}$ & $\begin{array}{r}0.40 \\
2.54 \\
40.63\end{array}$ & $\begin{array}{r}11.02 \\
25.91 \\
20.96 \\
.54\end{array}$ & $\begin{array}{r}1.21 \\
1.73 \\
23.42\end{array}$ & $\begin{array}{r}12.23 \\
31.59 \\
44.38 \\
.54\end{array}$ & $\begin{array}{r}7.87 \\
9.90 \\
34.54 \\
2.10\end{array}$ & $\begin{array}{r}7.87 \\
9.90 \\
40.15 \\
2.10\end{array}$ & $\begin{array}{r}19.29 \\
36.97 \\
61.31 \\
2.64\end{array}$ & $\begin{array}{rr}1.21 & \\
2.71 & 4.35 \\
61.11 & 2.74\end{array}$ & $\begin{array}{r}20.50 \\
44.03 \\
125.16 \\
2.64\end{array}$ \\
\hline Total. & 7.37 & 33.06 & 3.14 & 43. 57 & 58.43 & 26.36 & 88.74 & $5.61 \ldots$ & 60.02 & 120. 21 & 65.03 & 192.33 \\
\hline
\end{tabular}

Evans City $71 / 2$-minute quadrangle and east part of Zelienople $71 / 2$-minute quadrangle

Grand total.

\begin{tabular}{|c|c|c|c|c|c|c|c|c|c|c|c|c|c|c|c|}
\hline $\begin{array}{l}1.25 \\
1.85 \\
4.50 \\
3.00\end{array}$ & $\begin{array}{r}1.86 \\
.06 \\
2.40 \\
11.45 \\
1.31\end{array}$ & 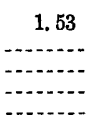 & $\begin{array}{r}4.64 \\
1.91 \\
2.40 \\
15.95 \\
4.31\end{array}$ & $\begin{array}{r}18.49 \\
42.43 \\
.41 \\
22.83 \\
11.82\end{array}$ & $\begin{array}{r}14.02 \\
.19 \\
4.73 \\
40.81 \\
.47\end{array}$ & - & $\begin{array}{r}32.51 \\
42.62 \\
5.14 \\
63.64 \\
12.29\end{array}$ & $\begin{array}{r}14.06 \\
3.25 \\
8.90 \\
53.08 \\
46.53\end{array}$ & $\begin{array}{r}1.60 \\
4.82 \\
26.38 \\
\end{array}$ & - & $\begin{array}{r}15.56 \\
3.25 \\
13.72 \\
79.46 \\
46.53\end{array}$ & $\begin{array}{r}33.80 \\
47.53 \\
9.31 \\
80.41 \\
61.35\end{array}$ & $\begin{array}{r}17.38 \\
.25 \\
11.95 \\
78.64 \\
1.78\end{array}$ & $\begin{array}{c}1.63 \\
\\
\end{array}$ & $\begin{array}{r}52.71 \\
47.78 \\
21.26 \\
159.05 \\
63.13\end{array}$ \\
\hline 10.60 & 17.08 & 1. 53 & 29.21 & 95.98 & 60.22 & & 156.20 & 125.82 & 32.70 & & 158. 52 & 232.40 & 110.00 & 1. 53 & 343.93 \\
\hline 81.08 & 2.14 & 9.73 & 412.95 & 5.03 & 35.87 & 40.03 & 90.93 & $1,147.77$ & 349.39 & 8.59 & $1,505.75$ & $1,893.88$ & $1,117.40$ & 35 & \\
\hline
\end{tabular}


TABLE 3.-Estimated original coal resources of Butler County, by thickness of overburden and by beds

[In millions of short tons]

\begin{tabular}{|c|c|c|c|c|c|c|c|c|c|c|c|c|c|c|c|c|}
\hline \multirow{2}{*}{$\begin{array}{l}\text { Coal bed having } \\
\text { indicated overburden }\end{array}$} & \multicolumn{4}{|c|}{ Measured resources } & \multicolumn{4}{|c|}{ Indicated resources } & \multicolumn{4}{|c|}{ Inferred resources } & \multicolumn{3}{|c|}{ Total for all categories } & \multirow{2}{*}{$\begin{array}{l}\text { Grand } \\
\text { total }\end{array}$} \\
\hline & $\begin{array}{l}\text { 14-28 } \\
\text { inches }\end{array}$ & $\begin{array}{l}28-42 \\
\text { inches }\end{array}$ & $\underset{\text { inches }}{>42}$ & Total & $\begin{array}{l}\text { 14-28 } \\
\text { inches }\end{array}$ & $\begin{array}{l}28-42 \\
s \text { inches }\end{array}$ & $\underset{\text { inches }}{>42}$ & Total & $\begin{array}{l}14-28 \\
\text { inches }\end{array}$ & $\begin{array}{l}28-42 \\
\text { inches }\end{array}$ & $\underset{\text { inches }}{>42}$ & Total & $\begin{array}{l}\text { 14-28 } \\
\text { inches }\end{array}$ & $\begin{array}{l}28-42 \\
\text { inches }\end{array}$ & $\underset{\text { inches }}{>42}$ & \\
\hline $\begin{array}{l}\text { Duquesne } \quad 0-60 \text { feet } \\
\text { Brush Creekek } \\
\text { Mahoning } \\
\text { Upper Freeport } \\
\text { Lower Freeport } \\
\text { Upper Kittanning } \\
\text { Middle Kittanning } \\
\text { Lower Kittanning } \\
\text { Serubgrass } \\
\text { Clarion } \\
\text { Brook }\end{array}$ & 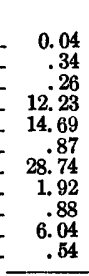 & $\begin{array}{r}0.11 \\
.20 \\
.29 \\
34.81 \\
12.40 \\
1.21 \\
71.12 \\
.35 \\
2.32 \\
27.62 \\
.69 \\
\end{array}$ & $\begin{array}{r}7.49 \\
4.76 \\
1.61 \\
.21 \\
2.10 \\
\end{array}$ & $\begin{array}{r}-0.15 \\
-\quad .54 \\
-54.53 \\
31.85 \\
2.08 \\
101.47 \\
-\quad 2.27 \\
3.41 \\
35.76 \\
-\quad 1.23 \\
\end{array}$ & $\begin{array}{r}4.29 \\
.69 \\
38.39 \\
45.84 \\
1.98 \\
28.58 \\
7.59 \\
.53 \\
8.88 \\
.52\end{array}$ & $\begin{array}{r}65.47 \\
20.56 \\
3.30 \\
19.01 \\
2.01 \\
14.95 \\
.84 \\
.18\end{array}$ & .45 & $\begin{array}{r}0.51 \\
4.70 \\
.69 \\
106.68 \\
74.81 \\
5.28 \\
47.59 \\
9.60 \\
1.48 \\
24.17 \\
.70\end{array}$ & $\begin{array}{r}14.31 \\
7.83 \\
3.95 \\
4.63 \\
4.11 \\
2.03 \\
3.07 \\
.87 \\
\end{array}$ & $\begin{array}{r}5.27 \\
1.75 \\
1.18 \\
2.26 \\
1.51 \\
.82 \\
\end{array}$ & a. & $\begin{array}{r}21.44 \\
10.59 \\
5.13 \\
6.89 \\
4.11 \\
3.54 \\
3.89 \\
.87 \\
\end{array}$ & $\begin{array}{r}0.04 \\
6.24 \\
.95 \\
64.93 \\
68.36 \\
6.80 \\
61.95 \\
13.62 \\
3.44 \\
17.99 \\
1.93\end{array}$ & $\begin{array}{r}0.56 \\
.66 \\
.29 \\
105.55 \\
34.71 \\
5.69 \\
92.39 \\
2.36 \\
4.78 \\
43.28 \\
.87 \\
\end{array}$ & $\begin{array}{r}12.17 \\
14.18 \\
1.61 \\
.21 \\
2.55 \\
\end{array}$ & $\begin{array}{r}0.66 \\
6.90 \\
1.24 \\
182.65 \\
117.25 \\
12.49 \\
155.95 \\
15.98 \\
8.43 \\
63.82 \\
2.80\end{array}$ \\
\hline Total & 66.55 & 151.12 & 16.17 & 233.84 & 137.29 & 127.18 & 11.74 & 276.21 & 42.41 & 12.84 & 2.87 & 58.12 & 246.25 & 291.14 & 30.78 & 568. 17 \\
\hline $\begin{array}{l}\text { Upper Freeport } \\
\text { Lower Freeport- } \\
\text { Upper Kittanning } \\
\text { Middle Kittanning } \\
\text { Lower Kittanning } \\
\text { Sorubgrass... } \\
\text { Clarion } \\
\text { Brook ville(?) }\end{array}$ & $\begin{array}{r}0.02 \\
8.90 \\
11.57 \\
1.90 \\
39.41 \\
6.54 \\
1.06 \\
11.59 \\
.09\end{array}$ & $\begin{array}{r}58.58 \\
4.23 \\
9.37 \\
118.22 \\
2.47 \\
.14 \\
88.77 \\
.36\end{array}$ & $\begin{array}{r}17.24 \\
3.66 \\
4.52 \\
2.74 \\
.01 \\
21.56 \\
-1.5 \\
\end{array}$ & $\begin{array}{r}0.02 \\
84.72 \\
19.46 \\
15.79 \\
160.37 \\
9.02 \\
-\quad 1.20 \\
121.92 \\
-\quad .45 \\
\end{array}$ & $\begin{array}{r}-\quad 0.05 \\
-\quad 2.35 \\
113.81 \\
207.10 \\
8.00 \\
131.80 \\
51.93 \\
4.58 \\
143.63 \\
1.09 \\
\end{array}$ & $\begin{array}{r}0.08 \\
241.77 \\
58.88 \\
18.35 \\
140.23 \\
8.84 \\
3.95 \\
11.98 \\
1.71\end{array}$ & 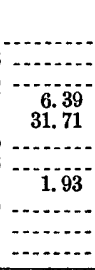 & $\begin{array}{r}0.05 \\
2.43 \\
.69 \\
362.05 \\
297.69 \\
26.35 \\
272.03 \\
62.70 \\
8.53 \\
155.61 \\
2.80\end{array}$ & $\begin{array}{r}21.06 \\
166.47 \\
36.71 \\
201.66 \\
449.70 \\
14.26 \\
51.46 \\
4.57\end{array}$ & $\begin{array}{r}64.38 \\
25.24 \\
4.82 \\
11.86 \\
53.03 \\
8.26 \\
81.61 \\
.19\end{array}$ & 8.59 & $\begin{array}{r}285.44 \\
200.30 \\
41.53 \\
313.52 \\
502.73 \\
22.52 \\
133.07 \\
4.76\end{array}$ & $\begin{array}{r}0.05 \\
4.23 \\
.63 \\
343.85 \\
385.14 \\
46.61 \\
372.87 \\
508.17 \\
19.90 \\
206.68 \\
5.75\end{array}$ & $\begin{array}{r}0.08 \\
.08 \\
364.73 \\
88.35 \\
32.54 \\
370.31 \\
64.34 \\
12.35 \\
182.36 \\
2.26\end{array}$ & $\begin{array}{r}23.63 \\
43.96 \\
4.52 \\
2.74 \\
1.94 \\
21.56\end{array}$ & $\begin{array}{r}0.05 \\
4.31 \\
732 \\
732.21 \\
517.45 \\
83.67 \\
745.92 \\
574.45 \\
32.25 \\
410.60 \\
8.01\end{array}$ \\
\hline Total. & 81.08 & 282.14 & 49.73 & 412.95 & 665.03 & 485.87 & 40.03 & $1,190.93$ & $1,147.77$ & $\begin{array}{r}349.39 \\
\end{array}$ & 8. 59 & $1,505.75$ & $1,893.88$ & $1,117.40$ & 98.35 & $3,109.63$ \\
\hline Grand total.... & 147.63 & 433.26 & 65.90 & 646.79 & 802.32 & 613.05 & 51.77 & $1,467.14$ & $1,190.18$ & 362.23 & 11.46 & $1,563.87$ & $2,140.13$ & $1,408.54$ & 129.13 & $3,677.80$ \\
\hline
\end{tabular}




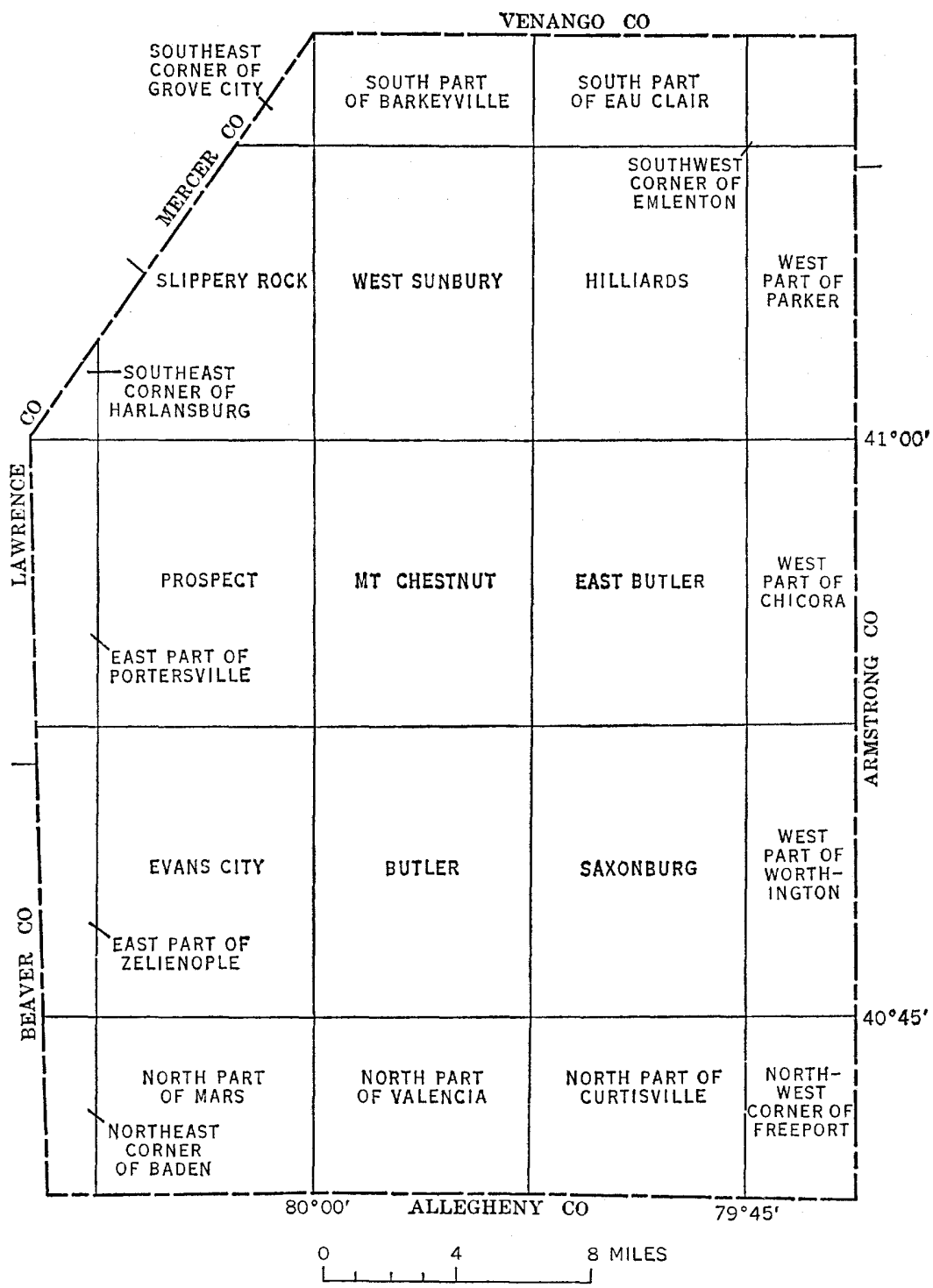

FIGURe 3.-Outline map of Butler County showing $7 \frac{1}{2}-$ minute-quadrangle areas used for breakdown of coal-resource data presented in tables 1 and 2.

As shown in table 4, of the 518 million tons of remaining resources in beds less than 60 feet below the surface that are readily accessible by strip-mining methods, 414 million is considered recoverable.

Of the total cumulative production of 126 million tons recorded between 1881 and January 1, 1966, about 40 million tons, or nearly 32 percent, has been obtained by strip-mining methods. In 1965, strip mining accounted for about 72 percent of total production. 
TABLE 4.- Estimated remaining and recoverable coal resources of Butler County as of January 1, 1966, according to thickness of overburden

[In millions of short tons]

\begin{tabular}{crrrrr}
\hline Overburden, in feet & $\begin{array}{l}\text { Original } \\
\text { resources }\end{array}$ & $\begin{array}{c}\text { Production } \\
1881-1965 \text { 1 }\end{array}$ & $\begin{array}{c}\text { Production } \\
\text { plus loss } \\
\text { in mining 2 }\end{array}$ & $\begin{array}{c}\text { Remaining } \\
\text { resources }\end{array}$ & $\begin{array}{c}\text { Recoverable } \\
\text { resources }\end{array}$ \\
\hline $\begin{array}{r}0-60 \text { feet } \\
60-1,000 \text { feet }\end{array}$ & 568 & 40 & 50 & 518 & $\begin{array}{r}414 \\
\text { Total }\end{array}$ \\
\hline
\end{tabular}

1 From Pennsylvania Dept. of Mines and Mineral Industries.

2 Based on assumption that recovery in strip mining is 80 percent and that recovery in underground mining is 50 percent.

\section{METHODS OF PREPARING ESTIMATES}

The estimates presented in tables 1-3 were prepared according to standard procedures of the U.S. Geological Survey and other agencies (Averitt, 1961, p. 12-25), as summarized below.

\section{CLASSIFICATION ACCORDING TO CHARACTERISTICS OF THE COAL}

Rank of coal.-Most of the coal in Butler County is of high-volatile $A$ bituminous rank as determined by standard procedures of the American Society for Testing and Materials. (See table 5.)

Weight of coal.-For uniformity in making calculations, all coal in Butler County was assumed to weigh 1,800 tons per acre-foot, or $1,152,000$ tons per square mile-foot.

Thickness of beds.-In tables 1-3 the resources are divided into three categories according to thickness of beds, as follows : 14-28 inches, 28-42 inches, and more than 42 inches. In Butler County, 58 percent of the estimated original resources is in the 14- to 28-inch category; 38 percent is in the 28 - to 42 -inch category; and only 4 percent is more than 42 inches thick.

Thickness of overburden.-All the minable coal in Butler County is less than 1,000 feet below the surface. Because most of the mining in the county is now by stripping methods, the resources in tables 1-3 are divided into two categories of overburden : $0-60$ feet and 601,000 feet. Most small stripping operations can recover coal with 60 feet or less of overburden, and most large underground mines penetrate deeper than 60 feet in order to obtain unoxidized coal. As shown in table 4 , about 15 percent of the estimated remaining resources in the county as of January 1,1966 , is in the 0 - to 60 -foot category, and 85 percent is in the 60 - to 1,000 -foot category.

\section{CLASSIFICATION AGCORDING TO RELATIVE ABUNDANGE OF INFORMATION}

The estimates of coal resources in Butler County are also divided into three categories according to the relative abundance of reliable 


\section{TABLE 5.-Classification of coals by rank}

[This classification does not include a few coals, principally nonbanded varieties, which have unusual physical and chemical properties and which come within the limits of fixed carbon or calorific value of the high-volatile bituminous and subbituminous ranks. All these coals either contain less than 48 percent dry, mineral-matter-free fixed carbon or have more than 15,500 moist, mineral-matter-free Btu per pound. From American Society for Testing and Materials (1967)]

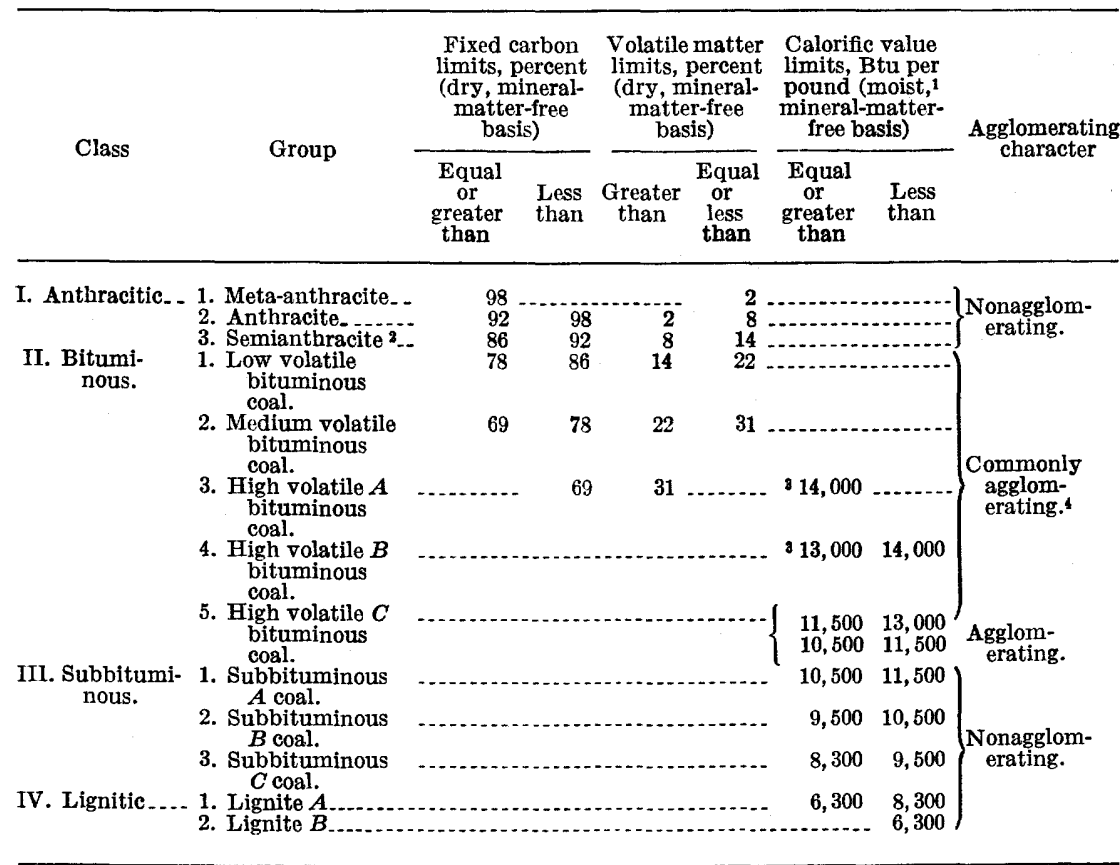

1 Moist refers to coal containing its natural inherent moisture but not including visible water on the surface of the coal.

2 If agglomerating, classify in low-volatile group of the bituminous class.

3 Coals having 69 percent or more fxed carbon on the dry, mineral-matter-free basis shall be classified according to fixed carbon, regardless of calorific value.

i It is recognized that there may be nonagglomerating varieties in these groups of the bituminous class, and there are notable exceptions in high-volatile $C$ bituminous group.

information available at the time of the study. These categories, designated "measured," "indicated," and "inferred," are defined below :

Measured resources are those for which tonnage is computed from the thickness of coal beds as revealed in outcrops, prospect openings, mine workings, and drill holes. The points of observation are so closely spaced and the thickness and extent of the coal so well defined that the computed tonnage is considered to be within 20 percent of the true tonnage. Although the spacing of points of observation necessary to demonstrate continuity of coal varies in different regions according to the character of the coal beds and the geologic structure, points of observation are generally about half a mile apart.

Indicated resources are those for which tonnage is computed partly from specific measurements and partly from assumptions based on the available data and on geologic evidence. In general, the points of 
coal measurements are about 1 mile apart, but they may be as much as $1 \frac{1}{2}$ miles apart for beds of known stratigraphic continuity.

Inferred resources are those for which quantitative estimates are based on a broad knowledge of the coal bed or region, and for which there are few, if any, direct measurements of coal. The estimates are based on an assumed continuity for which there is good geologic evidence gained during study of data on which calculations of measured and indicated resources were based. In general, inferred resources lie more than 2 miles from points of observed thicknesses.

Where continuity of bed thickness could not be established through regional correlations, the thickness of each bed was assumed to decrease regularly from the areas of measured resources across the areas of indicated and inferred resources.

In tables 1-3, the resource data are presented in the measured, indicated, and inferred categories. On plate 3, however, the measured and indicated categories are combined because the areas of measured resources were too small to show properly at the reduced scale of the bed maps.

\section{DISTINCTION BETWEEN ORIGINAL, REMAINING, AND RECOVERABLE RESOURCES}

As used in this report, original resources are the total resources in the ground before mining began. The tonnages cited in tables 1-3 are for original resources.

Remaining resources as of January 1, 1966, are the unmined resources remaining in the ground as of that date. The figures for remaining resources were obtained by subtracting from original resources the cumulative production through 1965 , plus an allowance for coal lost in past mining.

Recoverable resources as of January 1, 1966, are the resources considered to be recoverable in the future. The figures were obtained by subtracting from remaining resources the estimated future losses in mining.

The remaining and recoverable resources of Butler County were calculated on the assumption that in strip mining, both past and future, 80 percent of the coal in the ground is recovered and 20 percent is lost, and in underground mining 50 percent of the coal in the ground is recovered and 50 percent is lost. As shown in table 4, the remaining resources of Butler County as of January 1, 1966, totaled 3,456 million tons and the recoverable resources as of the same date totaled 1,883 million tons.

\section{METHODS OF REGORDING DATA AND MAKING GALCULATIONS}

The locations of the observed outcrops of coal beds in Butler County were plotted on the geologic map ( $p l .1$ ). The data for individual beds 
were then transferred and reduced to the individual bed maps (pl. 3). The lateral extent of each bed was then determined from outcrop, drill-hole, and mine data. Measurements of coal thicknesses from these sources were plotted on the bed maps, and thickness lines were drawn so as to divide the coal into the three thickness categories-14-28 inches, 28-42 inches, and more than 42 inches. Different degrees of shading were used to divide the bed into the (1) measured and indicated and (2) inferred categories, as defined above.

Within each of the areas thus defined, the average thickness of the coal was determined from the existing measurements. These measurements excluded all partings more than three-eighths of an inch thick and all parts of coal beds where the thickness of partings exceeded the thickness of coal.

The acreage in each category of resources was determined by use of a planimeter, and the tonnage of coal was calculated as follows: The number of acres times the average thickness of the coal, measured to the nearest tenth of a foot, times 1,800 , the assumed weight of coal, in tons per acre-foot. The results of the calculations are presented in tables 1-3.

\section{PREVIOUS ESTIMATES OF RESOURCES IN BUTLER COUNTY}

A previous estimate of coal resources in Butler County was prepared by Reese and Sisler (1928, p. 39-51) as part of a general study of the bituminous coal resources of Pennsylvania. The methods used by Reese and Sisler were similar to those used in the present study, but the earlier assumptions as to the minimum thickness of coal included, the number of beds included, and the specific gravity of the coal were more conservative than those used in the present estimate, as shown in the following table:

Comparison of past and present estimates of coal resourccs in Butler County

\begin{tabular}{|c|c|c|c|c|}
\hline \multirow[b]{2}{*}{ Source of estlmate } & \multirow[b]{2}{*}{$\begin{array}{l}\text { Estimated } \\
\text { original } \\
\text { resources } \\
\text { (millions of } \\
\text { short tons) }\end{array}$} & \multicolumn{3}{|c|}{ Assumptions used in preparing estimates } \\
\hline & & $\begin{array}{c}\text { Minimum } \\
\text { coal } \\
\text { thickness } \\
\text { (inches) }\end{array}$ & $\begin{array}{l}\text { Number } \\
\text { of beds } \\
\text { included }\end{array}$ & $\begin{array}{l}\text { Assumed } \\
\text { weight of } \\
\text { coal (tons per } \\
\text { acre-foot) }\end{array}$ \\
\hline $\begin{array}{l}\text { This report } \\
\text { Reese and Sisier }(1928) \\
\text { Ashley }(1944)\end{array}$ & $\begin{array}{r}3,678 \\
4,155 \\
14,570\end{array}$ & $\begin{array}{l}14 \\
18\end{array}$ & 11 & $\begin{array}{l}1,800 \\
1,688 \\
2\end{array}$ \\
\hline
\end{tabular}

1 The Reese and Sisler estimate increased 10 percent on the basis of findings in nearby areas.

In spite of the more conservative assumptions, the Reese and Sisler estimate of 4,155 million tons for the original rescurces of Butler County is about 12 percent larger than the present estimate of 3,678 million tons. This difference is explained by the fact that Reese and 
Sisler, working with much less data, assumed greater continuity for the Upper Kittanning and Brookville beds and thus obtained larger estimates for these beds, which could not be substantiated by the larger amount of data available for the present study. For all other beds, the estimates resulting from the present study are larger than the Reese and Sisler estimates, as shown in the following table:

Comparison of Reese and Sisler and present estimates of original coal resources in Butler County, by bed

[In millions of short tons]

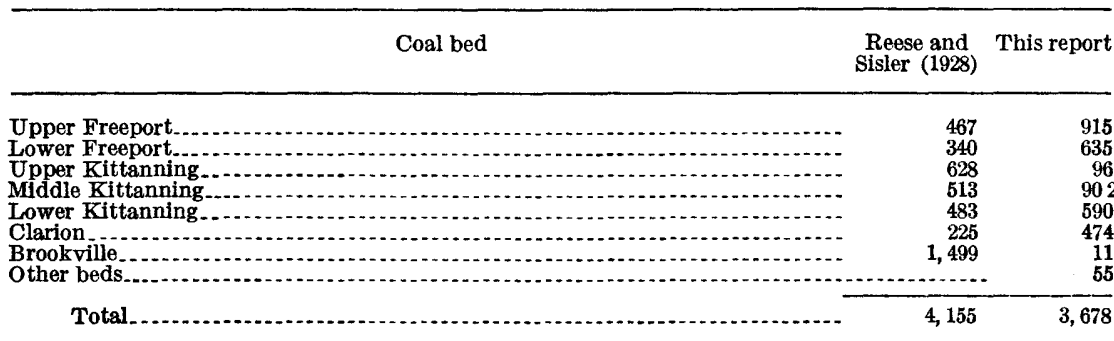

In a general report on the mineral resources of Pennsylvania, Ashley $(1944$, p. 83) proposed a larger figure of 4,570 million tons as the original resources in Butler County. This figure is a 10-percent increase in the Reese and Sisler estimate and was made by Ashley because detailed work in other parts of Pennsylvania after the Reese and Sisler estimate was prepared yielded larger totals.

The present estimate of 3,678 million tons for the original resources of the county is believed to be more accurate and useful than the older estimates of Reese and Sisler and of Ashley because it is based on a larger amount of information and because it is classified according to thickness of beds, thickness of overburden, and relative abundance of reliable information.

\section{QUALITY OF COAL}

Most of the coal in Butler County is of high-volatile $A$ bituminous rank and is relatively high in heat value. Analyses published by the U.S. Bureau of Mines (H. M. Cooper and R. F. Abernethy, in Ashley and others, 1939; Gray and Palowitch, 1960) show moisture contents ranging from 1.8 to 6.8 percent, volatile matter from 30.2 to 41.1 percent, sulfur from 0.9 to 6.4 percent, and ash from 4.4 to 17.2 percent, all calculated on the as-received basis. The average sulfur content is 2.8 percent, and the average ash content is 9.4 percent. Analyses of the Upper and Lower Freeport, Upper, Middle, and Lower Kittanning, Clarion, and Brookville(?) beds are presented in table 6. 
TABLE 6.-Analyses of coal in Butler County [Kind of sample: U, underground mine; S, strip mine; T, tipple. Form of analysis: 1, as received; 2, moisture free; 3, moisture and ash free. Rank: Hvab, high volatile $A$ bituminous;

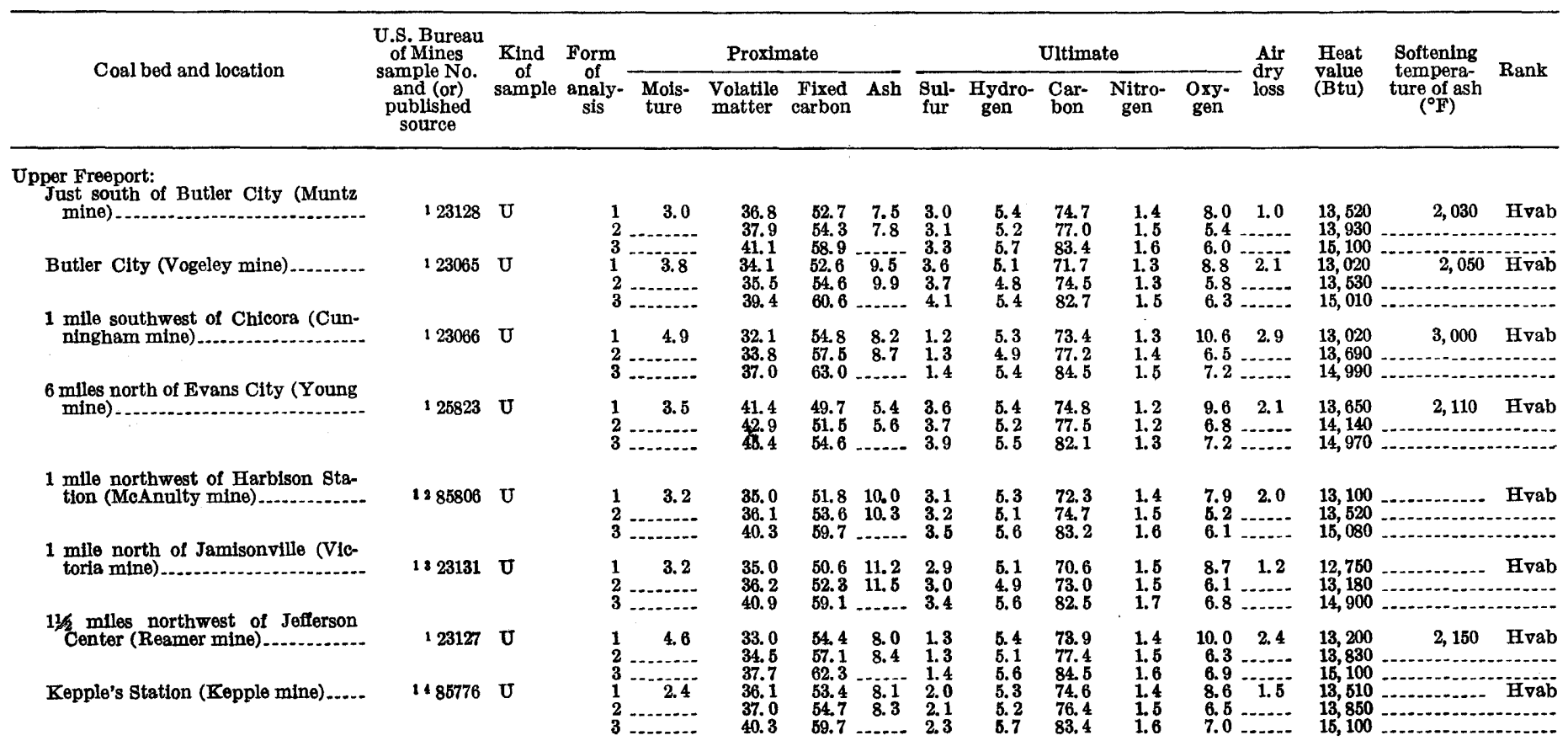


TABLE 6.-Analyses of coal in Butler County-Continued

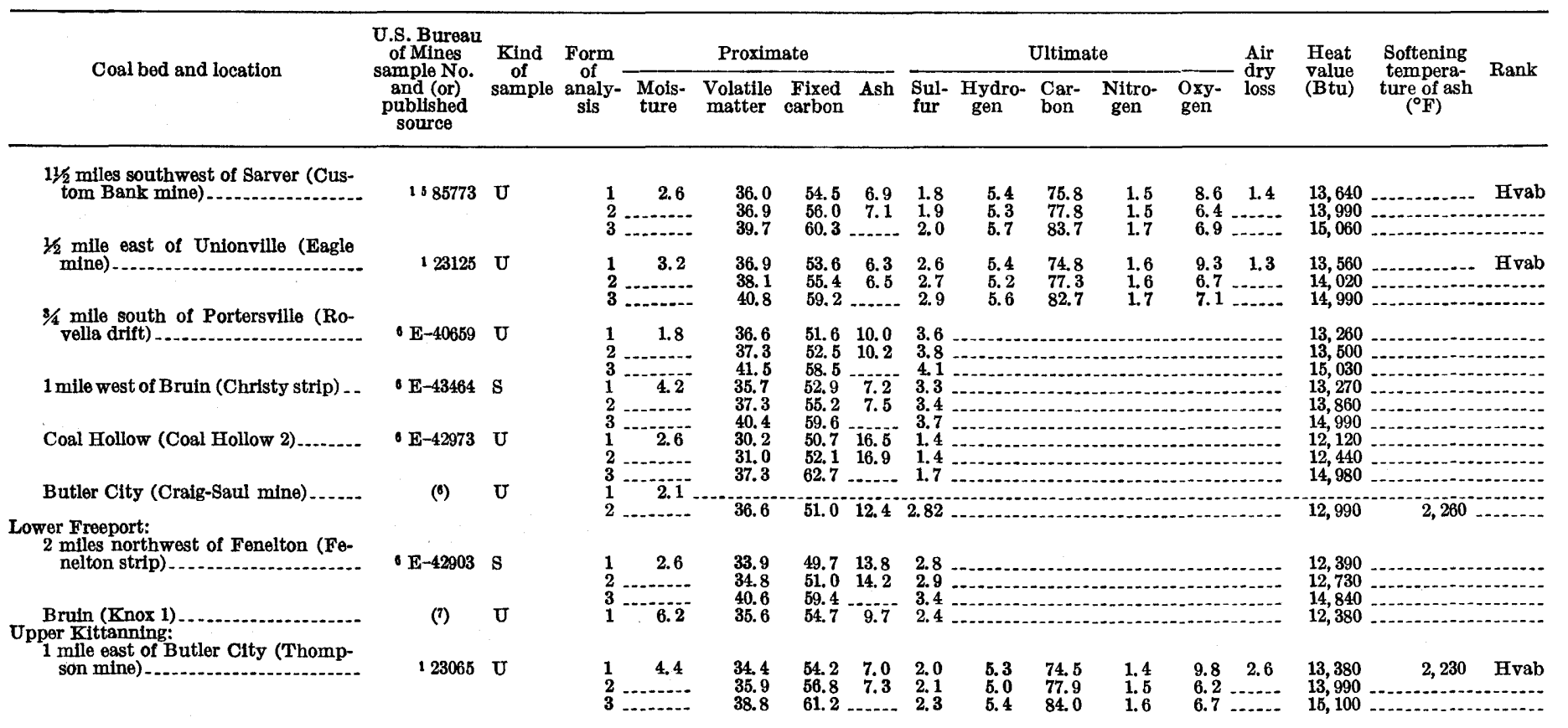


2 miles north of Butler City (Zenith

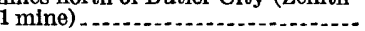

Evans City (Earle Faulk mine) .....

Middle Kittanning:

Claytonia (Stage mine)

Harmony Junction (North Pitts-

burg Realty mine) (No...............

Nealey (Nealey mine) -

5 miles south of Slippery Rock (Grossman strip)

3 miles south of Boyer (Farren strip).

Butler City (Taza 10 mine)

Forestville (Chutz mine)
Butler City (Smith strip)

Slippery Rock (Millerand McKnight strip) Annisville (Sunbeam strip)

Portersville (Stanford 2 mine) Lower Kittanning:

$21 / 2$ miles northeast of Zellenople
$1823134 \mathrm{U}$

E-42739 U

$123126 \quad U$

$125615 \quad U$

$125822 \quad U$

'E-41446 S

${ }^{6} \mathrm{E}-43385 \quad \mathrm{~S}$

(7) T

6 $\mathrm{E}-40828 \mathrm{~S}$

(6) $\mathrm{S}$

(8) $\mathrm{S}$

(10) $\mathrm{T}$

- E-42497 $\begin{array}{lc}1 & 3.7 \\ 2 & -1 .- \\ 3 & -1.6 \\ 1 & 1.6 \\ 2 & -\cdots-\end{array}$

35.8
37.2
39.0
34.7
35.2
4.7

$\begin{array}{lr}1 & 3.7 \\ 2 & 3.7\end{array}$

\section{5,4}

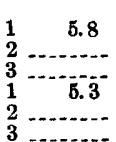

36.8
42.8

37.9
40.2
45.4

$\mathbf{4 5 .} 4$
$\mathbf{3 6 . 5}$
$\mathbf{3 8 . 6}$$$
124
$$

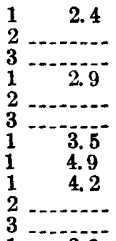

36.6
37.6
42.9

37.6
42.9

35.0

38.2

39.2

34.5
36.0 34.5
36.0
39.5

$\begin{array}{ll}1 & 2.8 \\ 2 & \\ 1 & 2.0 \\ 2 & -3.0\end{array}$

38.0

$3^{3}$

.9
.9
6.4

$\begin{array}{rrrrrr}5.5 & 77.3 & 1.5 & 10.4 & 1.7 & 13,860 \\ 5.3 & 80.3 & 1.6 & 7.4 & \ldots . . . & 14,400\end{array}$

$\begin{array}{ll}56.1 & 4.4 \\ 58.3 & 4.5\end{array}$

46. $5-17.2$

$\mathbf{4 7 . 3}$
$\mathbf{5 7 . 3}$

$\begin{array}{llllll}5.3 & 80.3 & 1.6 & 7.4 & -\ldots- & 14,00 \\ 5.5 & 84.1 & 1.7 & 7.7 & -\cdots & 15,080\end{array}$

7.9

14,800

$\begin{array}{lllllllll}47.4 & 13.5 & 3.8 & 5.2 & 68.4 & 1.3 & 7.8 & 2.0 & 12,410 \\ 49.2 & 14.0 & 3.9 & 5.0 & 71.1 & 1.4 & 4.6 & -\ldots & 12,890\end{array}$

2, 130 Hvab

57.214 .0

$\begin{array}{ll}5.2 & 68.4 \\ \mathbf{5 . 0} & \mathbf{7 1 . 1} \\ \mathbf{5 . 8} & \mathbf{8 2 . 6}\end{array}$

$\begin{array}{lllllllll}45.6 & 10.7 & 4.3 & 5.7 & 68.6 & 1.2 & 9.5 & 4.6 & 12,450\end{array}$

$\begin{array}{lll}48.4 & 11.4 & 4.5 \\ 54.6 & & 5.1\end{array}$

$\begin{array}{lll}54.6 & -7.0 & 5.1 \\ 48.0 & 10.2 & 3.7\end{array}$

$50.6 \quad 10.8 \quad 3.9$

$\begin{array}{lll}5.4 & 72.8 & 1.3\end{array}$

$\begin{array}{ll}\mathbf{5 . 4} & \mathbf{8 2 . 2} \\ \mathbf{6 . 4} & 69.4 \\ \mathbf{5 . 0} & \mathbf{7 3 . 3}\end{array}$

1.6
1.5 .2

12,450
13,210

$\begin{array}{ll}48.9 & 12.1 \\ 55.0 & 12.4\end{array}$

$\begin{array}{ll}5.6 & 82.2\end{array}$

$1.3 \quad 5.7-\ldots . .$.

12,580

57,1

55.18 .0

56.7

. 3.7

$5.0 \quad 9.0 \quad 1.4$

60.5 ..... 1.5 . 5 .

12,780

14,950
13,400

13,790

12,940

12,330 2,060 Hvab

13,640 (3)

14,990

$13,530 \quad 2,130, \ldots .$.

$\begin{array}{ll}12,860 & 2,060 \\ 12,750 & 2,080\end{array}$

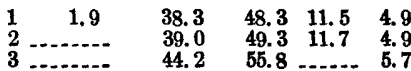

13,090

13,330 
TABLE 6.-Analyses of coal in Butler County-Continued

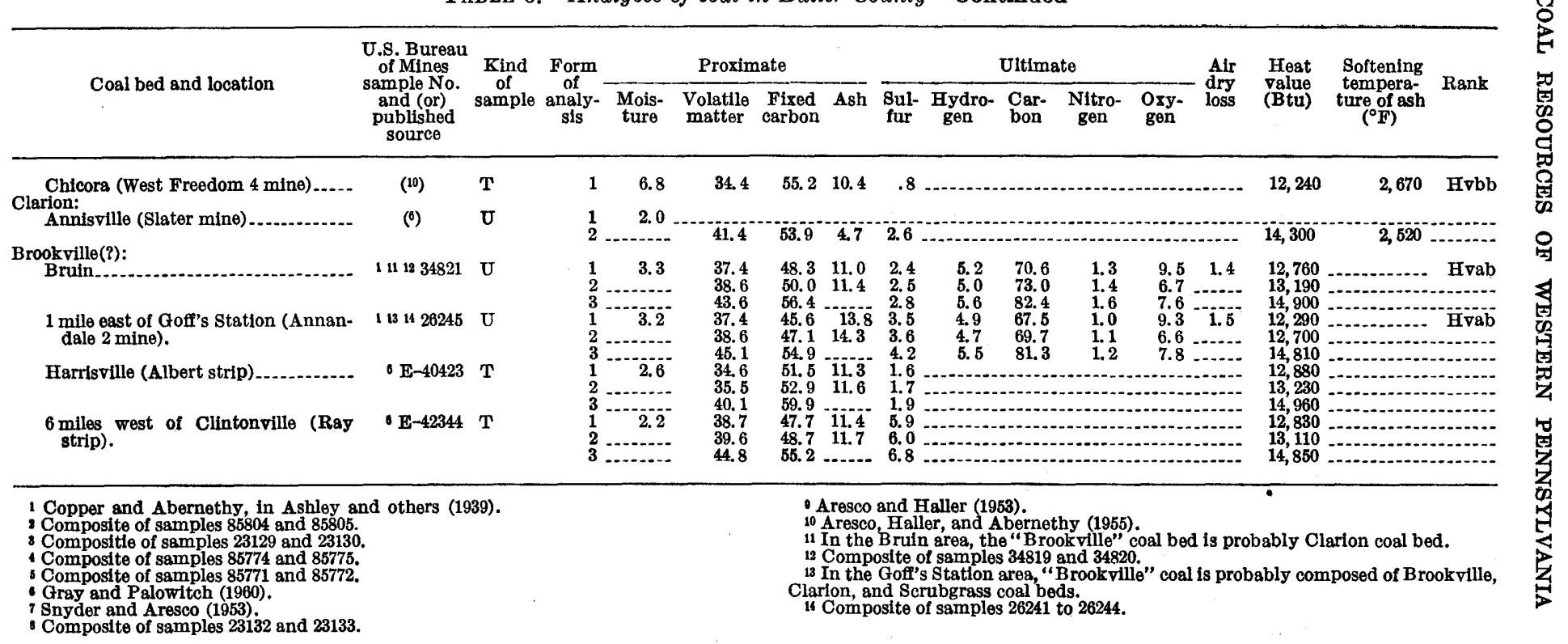


According to Gray and Palowitch (1960), the Upper Freeport, Upper and Lower Kittanning, and Brookville(?) beds at localities where the sulfur content is low can, by proper crushing and washing, be upgraded to metallurgical coke. The Lower Kittanning and Clarion beds are higher in sulfur and are less amenable to beneficiation.

\section{PRODUCTION OF COAL}

As recorded by the Pennsylvania Department of Mines (Maize and Struble, 1955) and by the U.S. Bureau of Mines (1933-67), the cumulative coal production in Butler County from 1881 through 1965 was about 126 million tons. About 68 percent of this total was obtained by underground mining methods and about 32 percent by strip-mining methods. In the early days of mining, all production was by underground methods. The transition to strip mining began in the late 1930's and early 1940's, and since this period the amount of coal recovered by strip mining has increased annually. By 1945, strip mining accounted for about half the annual production, and in 1965, strip mining accounted for a record 72 percent of the total recorded production. Mining is heavily concentrated in the Upper Freeport and Middle Kittanning beds. The annual production of coal in Butler County from 1881 through 1965 is shown graphically in figure 4, and the annual production, expressed as a percentage of total production of bituminous coal in Pennsylvania, is shown in figure 5.

\section{CONCLUSIONS}

As noted in previous tables, Butler County contains large coal resources potentially recoverable by strip-mining methods. Table 4 shows that 15 percent of the estimated resources as of January 1 , 1966 , is generally less than 60 feet below the surface. By a process of extrapolation, about 25 percent should be generally less than 100 feet below the surface. All the coal is less than 1,000 feet below the surface.

Because of the rapid increase in strip mining, accompanied by a trend toward use of larger machinery, deeper mining, and multiplebed stripping, the percentage of Butler County coal within reach by future strip-mining techniques could be larger than the figures mentioned above. 


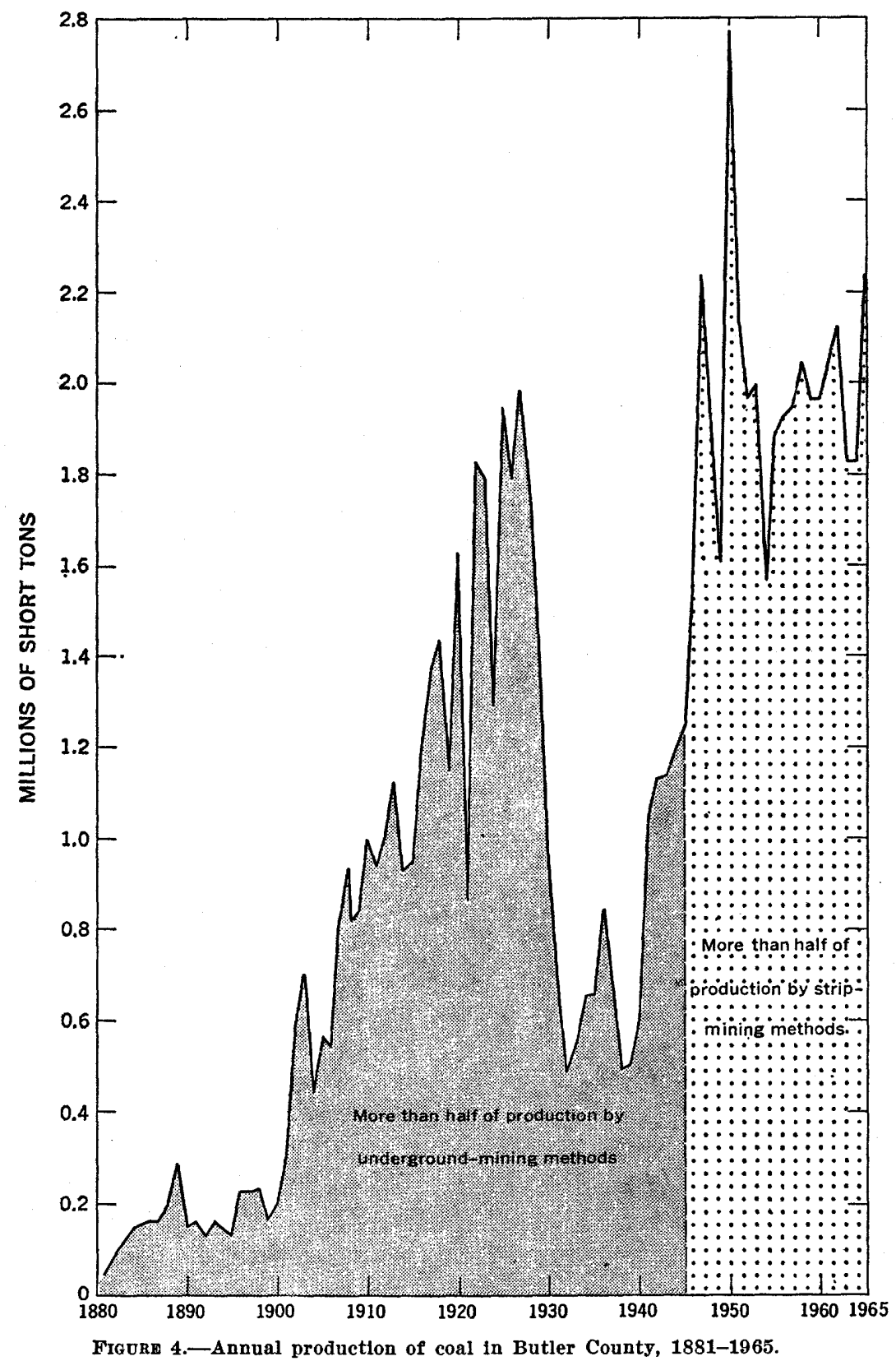




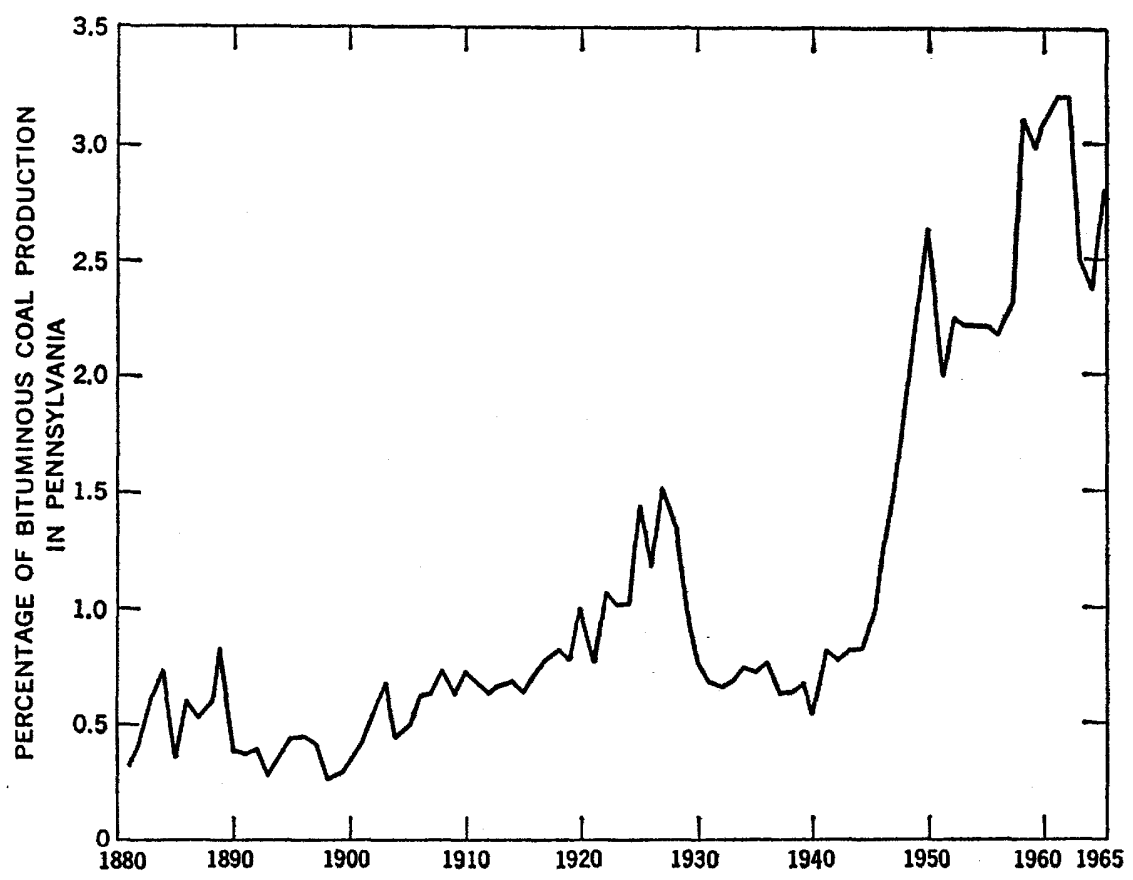

Figure 5.-Production of coal in Butler County, expressed as percentage of total production of bituminous coal in Pennsylvania, 1881-1965.

\section{SELECTED REFERENCES}

American Society for Testing and Materials, 1967, Standard specifications for classification of coals by rank (ASTM designation: D388-66), in 1967 book of ASTM standards, with related material-Part 19, Gaseous fuels; Coal and coke : Philadelphia, p. 73-78.

Aresco, S. J., and Haller, C. P., 1953, Analyses of tipple and delivered samples of coal (collected during the fiscal year 1952) : U.S. Bur. Mines Rept. Inv. $4972,84 \mathrm{p}$.

Aresco, S. J., Haller, C. P., and Abernethy, R. F., 1955, Analyses of tipple and delivered samples of coal (collected during the fiscal year 1953) : U.S. Bur. Mines Rept. Inv. 5085, $82 \mathrm{p}$.

Ashley, G. H., 1926, Punxsutawney quadrangle ; geology and mineral resources: Pennsylvania Geol. Survey, 4th ser., Atlas 65, 145 p.

1944, Coal, in Pennsylvania Bur. Statistics and Inf., Pennsylvania's mineral heritage: Harrisburg, Pa., Pennsylvania Dept. Int. Affairs, p. 77-86.

Ashley, G. H., and others, 1939, Analyses of Pennsylvania bituminous coals: U.S. Bur. Mines Tech. Paper 590, 503 p.

Averitt, Paul, 1961, Coal reserves of the United States-A progress report, January 1, 1960 : U.S. Geol. Survey Bull. 1136, 116 p.

Butts, Charles, 1904, Description of the Kittanning quadrangle [Pennsylvania]: U.S. Geol. Survey Geol. Atlas, Folio 115, 15 p.

1906, Economic geology of the Kittanning and Rural Valley quadrangles, Pennsylvania : U.S. Geol. Survey Bull. 279, 198 p. 
Carswell, L. D., and Bennett, G. D., 1963, Geology and hydrology of the Neshannock quadrangle, Mercer and Lawrence Counties, Pennsylvania : Pennsylvania Geol. Survey, 4th ser., Bull. W15, 90 p.

Chance, H. M., 1879, The northern townships of Butler County; a special survey along the Beaver and Shenango Rivers in Beaver, Lawrence, and Mercer Counties : Pennsylvania Geol. Survey, 2d ser., Rept. V, 248 p.

Fettke, C. R., 1961, Well-sample descriptions in northwestern Pennsylvania and adjacent States: Pennsylvania Geol. Survey, 4th ser., Bull. M40, $691 \mathrm{p}$.

Ford, Bacon, \& Davis, Inc., Engineers, 1952, The synthetic liquid fuel potential of Pennsylvania. Report for Bureau of Mines, Department of the Interior: New York, [518 p.].

Graeber, C. K., and Foose, R. M., 1942, Brookville quadrangle; geology and mineral resources: Pennsylvania Geol. Survey, 4th ser., Atlas 54, $136 \mathrm{p}$.

Gray, T. E. and Palowitch, E. R., 1960, Preparation characteristics of coal from Butler County, Pennsylvania : U.S. Bur. Mines Rept. Inv. 5609, 49 p.

Hughes, H. H., 1933, Freeport quadrangle; geology and mineral resources: Pennsylvania Geol. Survey, 4th ser., Atlas 36, 272 p.

Lesley, J. P., 1876, The Boyd's Hill gas well at Pittsburgh: Pennsylvania Geol. Survey, $2 d$ ser., Rept. L, p. 217-237.

Mazie, C. H., and Struble, G. S., compilers, 1955, History of Pennsylvania bituminous coal : Harrisburg, Pa., Pennsylvania Dept. Mines, 65 p.

Munn, M. J., 1911, Description of the Sewickley quadrangle [Pennsylvania] : U.S. Geol. Survey Geol. Atlas, Folio 176, 16 p.

Patterson, E. D., 1963, Coal resources of Beaver County, Pennsylvania: U.S. Geol. Survey Bull. 1143-A, 33 p.

Platt, Franklin, 1875, Report of progress in the Clearfield and Jefferson district of the bituminous coal fields of western Pennsylvania: Pennsylvania Geol. Survey, 2d ser., Rept. H, 296 p.

Platt, Franklin, and Platt, W. G., 1877, Report of progress in the Cambria and Somerset district of the bituminous coal fields of western Pennsylvania ; Part II, Somerset : Pennsylvania Geol. Survey, 2d ser., Rept. H3, 348 p.

Platt, W. G., 1881, Report of progress in Jefferson County : Pennsylvania Geol. Survey, 2d ser., Rept. H6, 218 p.

Poth, C. W., 1963, The geology and hydrology of the Mercer quadrangle, Mercer, Lawrence, and Butler Counties, Pennsylvania: Pennsylvania Geol. Survey, 4th ser., Bull. W16, 149 p.

Preston, F. W., 1950, Introduction to glacial Lake Arthur, in Field Conf. Pennsylvania Geologists. 16th, 1950, Guidebook: Harrisburg, Pa., Pennsylvania Geol. Survey, p. 12-36.

Rayburn, J. M., 1924, The deposit of double-thick Upper Freeport coal situated in the valley of Allegheny River in Allegheny, Butler, and Westmoreland Counties, Pennsylvania: Engineers' Soc. Western Pennsylvania, Proc., v. 40, no. 1, p. $27-44$.

Reese, J. F., and Sisler, J. D., 1928. Coal resources, Part 3 of Introductory volume of Bituminous coal flelds of Pennsylvania : Pennsylvania Geol. Survey, 4th ser., Bull. M6, pt. 3, 153 p.

Renick, B. C., 1924, The correlation of the Lower Allegheny-Pottsville section in western Pennsylvania : Jour. Geology, v. 32, no. 1, p. 64-80.

Richardson, G. B., 1932, Geology and coal, oil, and gas resources of the New Kensington quadrangle, Pennsylvania: U.S. Geol. Survey Bull. 829, 102 p. 
1936, Geology and mineral resources of the Butler and Zelienople quadrangles, Pennsylvania : U.S. Geol. Survey Bull. 873, 93 p.

Rogers, H. D., 1840, Fourth annual report on the geological exploration of the State of Pennsylvania : Harrisburg, Pa., $215 \mathrm{p}$.

1858, The geology of Pennsylvania, a government survey: Philadelphia, J. B. Lippincott and Co., 2 v.

Shaw, E. W., Lines, E. F., and Munn, M. J., 1911, Description of the FoxbrurgClarion quadrangle, Pennsylvania: U.S. Geol. Survey Geol. Atlas, Folio 178, $18 \mathrm{p}$.

Shaw, E. W., and Munn, M. J., 1911, Coal, oil, and gas of the Foxburg quadrangle, Pennsylvania : U.S. Geol. Survey Bull. 454, 85 p.

Shepps, V. C., White, G. W., Droste, J. B., and Sitler, R. F., 1959, Glacial geology of northwestern Pennsylvania: Pennsylvania Geol. Survey, 4th ser., Bull. G32, $59 \mathrm{p}$.

Sherrill, R. E., and Matteson, L. S., 1939, Geology of the oil and gas fields of the Hilliards quadrangle [advance rept.] : Pennsylvania Geol. Survey, 4th ser., Bull. 122, 25 p.

Sisler, J. D., 1932, Detailed description of coal fields [2d ed.], Part 2 [of Introductory volume] of Bituminous coal fields of Pennsylvania: Pennsylvania Geol. Survey, 4th ser., Bull. M6, pt. 2, 511 p.

Snyder, N. H., and Aresco, S. J., 195̄3, Analyses of tipple and delivered samples of coal (collected during the fiscal years 1948 to 1950 , inclusive) : U.S. Bur. Mines Bull. 516, 133 p.

Stevenson, J. J., 1873, Notes on the geology of West Virginia : Am. Philos. Soc. Trans., new ser., v. 15, p. 15-32.

Swartz, C. K., 1922, Distribution and stratigraphy of the coal measures of Maryland and Correlation of the coal measures of Maryland and The coal basins of Maryland : Maryland Geol. Survey, v. 11, p. 35-79, 81-106, 109-129.

U.S. Bureau of Mines, 1933-67, Minerals Yearbook [1932-65] : Washington, U.S. Govt. Printing Office (annual volumes for the years indicated).

Van Lieu, J. A., and Patterson, E. D., Coal resources of Lawrence County, Pennsylvania: U.S. Geol. Survey Bull. 1143-B, 33 p.

White, I. C., 1878, Report of progress in the Beaver River district of the bituminous coal fields of western Pennsylvania: Pennsylvania Geol. Survey, 2d ser., Rept. Q, 337 p.

1879, The geology of Lawrence County; to which is appended a special report on the correlation of the coal measures in western Pennsylvania and eastern Ohio: Pennsylvania Geol. Survey, 2d ser., Rept. Q2, 336 p.

1880, The geology of Mercer County : Pennsylvania Geol. Survey, 2d ser., Rept. Q3, 233 p.

1891, Stratigraphy of the bituminous coal field of Pennsylvania, Ohio, and West Virginia : U.S. Geol. Survey Bull. 65, 212 p. 


$$
\text { - }
$$



